\title{
Asynchronous evolution of the Indian and East Asian Summer Monsoon indicated by Holocene moisture patterns in monsoonal central Asia
}

\author{
Yongbo Wang ${ }^{\mathrm{a}, \mathrm{b}}$, Xingqi Liu ${ }^{\mathrm{c}}$, Ulrike Herzschuh ${ }^{\mathrm{a}, \mathrm{b}, *}$ \\ a Alfred Wegener Institute for Polar and Marine Research, Research Unit Potsdam, 14473 Potsdam, Germany \\ b Department of Geoscience, University of Potsdam, Karl-Liebknecht-Str.24, 14476 Golm, Germany \\ c State Key Laboratory of Lake Science and Environment, Nanjing Institute of Geography and Limnology, Chinese Academy of Sciences, 210008 Nanjing, PR China
}

\section{A R T I C L E I N F O}

\section{Article history:}

Received 4 December 2009

Accepted 15 September 2010

Available online 30 October 2010

\section{Keywords:}

moisture evolution

East Asian Summer Monsoon

Indian Summer Monsoon

numerical analysis

monsoonal central Asia

Holocene

monsoon index

\begin{abstract}
A B S T R A C T
The numerical meta-analysis of 92 proxy records ( 72 sites) of moisture and/or temperature change confirms earlier findings that the dominant trends of climatic evolution in monsoonal central Asia since the Last Glacial roughly parallel changes in Northern Hemisphere summer insolation, i.e. the period following the Last Glacial Maximum was characterized by dry and cold conditions until 15 cal. kyr BP, followed by a warm, wet period coincident with the Bølling/Allerød warm period and terminated by a cold, dry reversal during the Younger Dryas period. After an abrupt increase at the start of the Holocene, warm and wet conditions prevailed until ca. 4 cal. kyr BP when moisture levels and temperatures started to decrease.

Ordination of moisture records reveals strong spatial heterogeneity in moisture evolution during the last 10 cal. kyr. The Indian Summer Monsoon (ISM) areas (northern India, Tibetan Plateau and southwest China) exhibit maximum wet conditions during the early Holocene, while many records from the area of the East Asian Summer Monsoon indicate relatively dry conditions, especially in north-central China where the maximum moisture levels occurred during the mid-Holocene. We assign such phenomena to strengthened Hadley Circulation centered over the Tibetan Plateau during the early Holocene which resulted in subsidence in the East Asian monsoonal regions leading to relatively dry conditions. Our observations of the asynchronous nature of the two Asian monsoon subsystems on millennial time scales have also been observed on annual time-scales as well as implied through the spatial analysis of vertical air motion patterns after strong ascending airflows over the Tibetan Plateau area that were calculated from NCEP/NCAR reanalysis data for the last 30 years. Analogous with the early Holocene, the enhancement of the ISM in a 'future warming world' will result in an increase in the asynchronous nature of the monsoon subsystems; this trend is already observed in the meteorological data from the last 15 years.
\end{abstract}

(c) 2010 Published by Elsevier B.V.

\section{Contents}

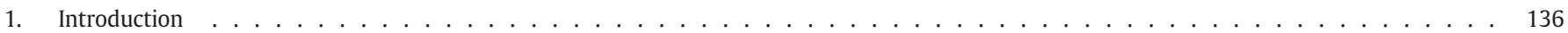

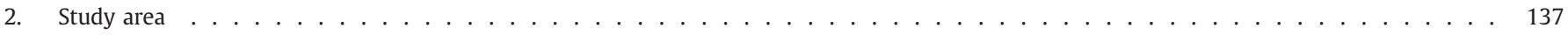

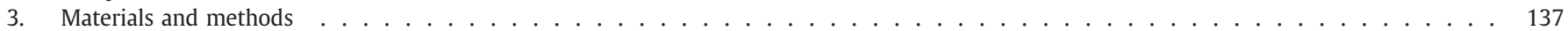

3.1. Selection of palaeoclimatic records . . . . . . . . . . . . . . . . . . . . . . . . . . . . . 137

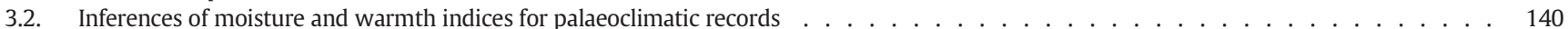

3.3. Mapping and ordination of palaeomoisture index results . . . . . . . . . . . . . . . . . . . . . . . . . . . . . . 140

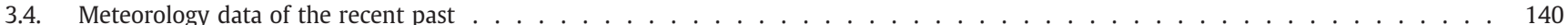

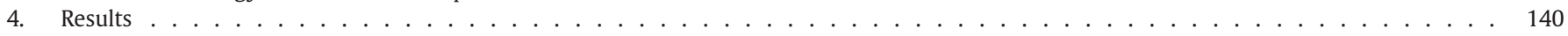

4.1. Variations in the mean moisture and warmth indices . . . . . . . . . . . . . . . . . . . . . . . . . . 140

4.2. Frequency of impacts of anthropogenic activity . . . . . . . . . . . . . . . . . . . . . . . . 141

4.3. Temporal and spatial analysis of PCA axes scores . . . . . . . . . . . . . . . . . . . . . . . . . . 141

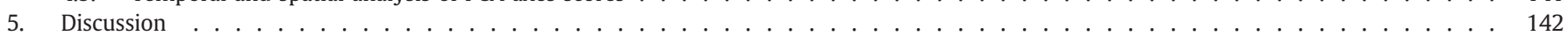

5.1. Reliability of climate inferences from proxy records in monsoonal central Asia . . . . . . . . . . . . . . . . . . . . 142

\footnotetext{
* Corresponding author. Alfred Wegener Institute for Polar and Marine Research in the Helmholtz Association, Telegraphenberg A43, 14473 Potsdam, Germany. Tel.: + 49 331 288 2165 ; fax: +493312882137

E-mail address: Ulrike.Herzschuh@awi.de (U. Herzschuh).
} 
5.2. Spatial and temporal climate patterns in monsoonal central Asia since 18 cal. kyr BP . . . . . . . . . . . . . . . . . . . . . . 142

5.3. The asynchronous nature of the Asian monsoonal subsystems: past and present . . . . . . . . . . . . . . . . . . . . . . 146

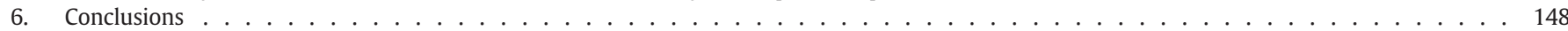

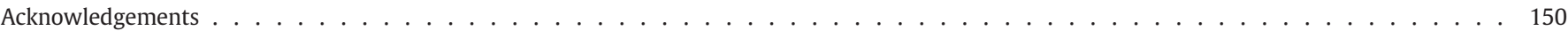

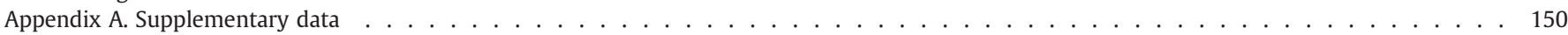

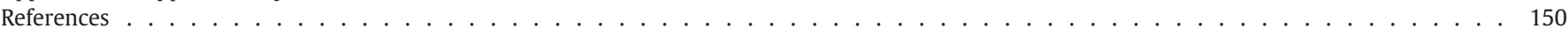

\section{Introduction}

The monsoonal regions of central Asia are assumed to be particularly vulnerable to past and present climatic change as they represent the transition zone between three circulation systems; the Indian Summer Monsoon (ISM), the East Asian Summer Monsoon (EASM) and the Westerlies (Fig. 1) (Porter and An, 1995; B. Wang, et al., 2001; Hong, et al., 2005; Wang, 2006; Clift and Plumb, 2008).

In recent years, several studies have attempted to reconstruct lateQuaternary climatic histories by reviewing published proxy records in a descriptive manner; however, these have displayed inconsistent trends and contradictory explanations. An et al. (2000) first reported an asynchronous Holocene Optimum in different regions of China, which appeared ca. 9000 years ago in north and northeast China, and as late as 3000 years ago in south and southeast China. In contrast, He et al. (2004) found a west-east trend. By applying a consistent methodology to infer effective moisture from proxy records, Herzschuh (2006) found only slight differences in the temporal moisture patterns between the ISM, EASM and Westerlies. The 'out-of-phase' relationship between arid central Asia and eastern Asia observed by Chen et al. (2008) was explained by differences in the moisture evolution between areas influenced by the mid-latitude Westerlies and areas that are dominated by the Asian Summer Monsoon. Maher (2008) argued that temporal differences between the Indian and the East Asian monsoonal moisture maximum may origin from differences in the seasonality of both monsoon systems.

Furthermore differing opinions exist concerning the temporal relationship between insolation variations and monsoonal strength. Although most authors agree that the monsoonal maximum lags behind the insolation maximum, they have inferred different lag times (3000 yrs, Overpeck et al., 1996; 1500 yrs, Fleitmann et al., 2007); and two contrasting ideas exist concerning a gradual (Overpeck et al., 1996; Y.J. Wang et al., 2005; Fleitmann et al., 2007) versus an abrupt (Morrill et al., 2003) monsoon retreat pattern.

The external and internal forcing mechanisms of the Asian Summer Monsoon are key to understanding regional moisture patterns, however are still under debate. It is widely accepted that monsoonal changes on millennial or longer time-scales are predominantly forced by orbitally-induced changes in solar insolation and subsequent shifts in the position of the ITCZ (Sirocko et al., 1993; Overpeck et al., 1996; Y.J. Wang et al., 2001, 2005; Fleitmann et al., 2003; P.X. Wang et al., 2005; Fleitmann et al., 2007). Smaller monsoonal oscillations that are observed on decadal to annual timescales were assumed to be affected by the solar activity through the "transfer effect" of the northern Atlantic Ocean (Y.J. Wang et al., 2005). Hypotheses concerning internal driving mechanisms focus on the effects of the thermal contrast between the Eurasian continent and the surrounding oceans, exerted by changes in oceanic thermohaline circulation (Webster et al., 1998), sea surface temperatures (SST) (Bush, 2001,2005), teleconnections in atmospheric circulation (Y.J. Wang, et al., 2005) and/or high-latitude ice volume (Overpeck et al., 1996). In addition, results from general climate models demonstrate that the relative position of the westerly jet to the Tibetan Plateau probably also affected monsoon evolution (Sato, 2009).

Using meteorological data available for the last 50 years, various monsoon indices were constructed to trace recent interannual variability in the monsoonal circulation and its subsystems (the ISM and the EASM) (Webster and Yang, 1992; Goswami et al., 1999; B. Wang et al., 2001; Huang, 2004). Different interannual variations between the two subsystems are related to different convectional

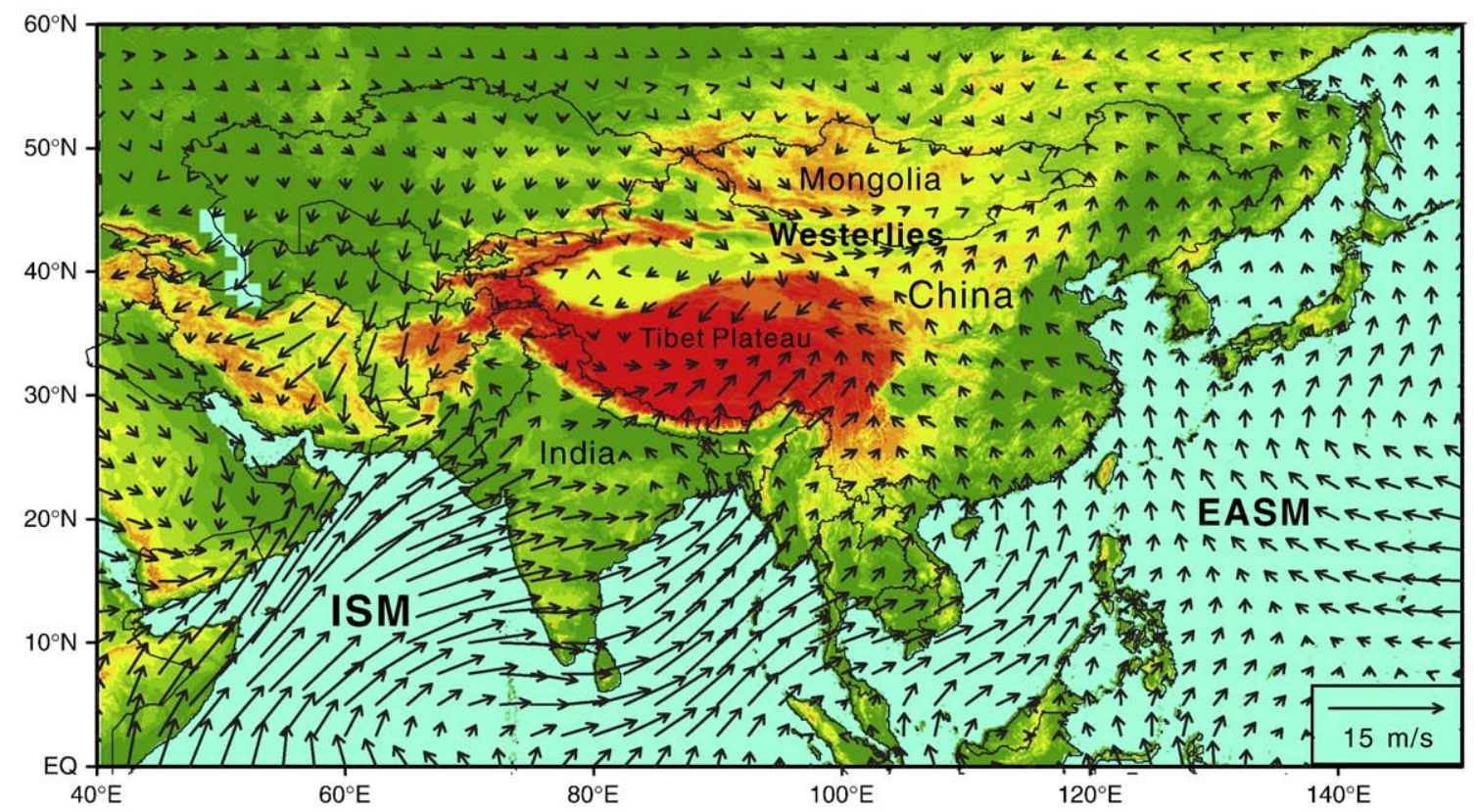

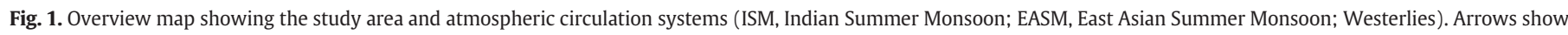
60-year mean summer (June, July, August) wind fields based on NCEP/NCAR reanalysis data (Level 1000 hPa) from Jan. 1948 to Dec. 2008. 


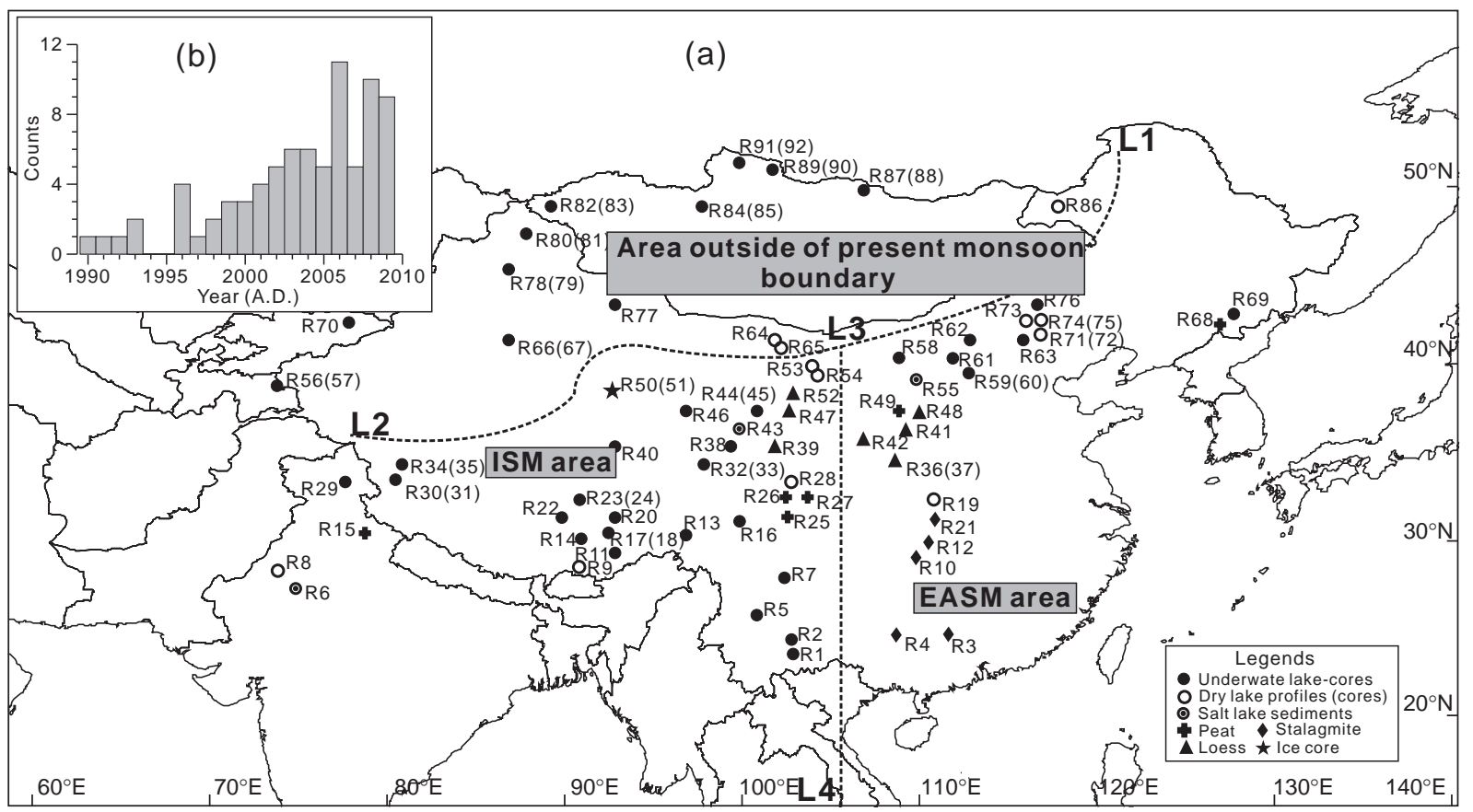

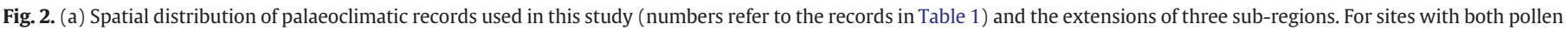

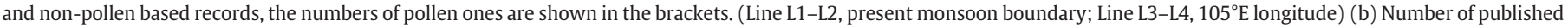
records during the last 20 years.

heat sources assumed to originate from either changing summer SSTs (Goswami et al., 1999; Zveryaev and Aleksandrova, 2004) or El NinoSouthern Oscillation (ENSO) (Chang et al., 2000; B. Wang et al., 2001).

Numerous new records and further information based on previous work have been published in the last 3 years (Fig. 2b), necessitating the development of a new synthetical review. Herewith, we provide a statistical meta-analysis of moisture patterns in monsoonal central Asia, as inferred from proxy records covering the last 18,000 years compared with spatial information concerning recent monsoonal development derived from NCEP/NCAR reanalysis data (National Centre for Environmental Prediction/National Centre for Atmospheric Research). We aim to: (1) synthesize the spatial and temporal patterns of moisture evolution in the monsoonal regions of central Asia, extending the data set by Herzschuh (2006); (2) investigate their relationships with extra-regional and global climate trends to identify potential forcing mechanisms, and (3) investigate the suppressant effect of the ISM on the EASM on both millennial and annual time-scales. From the comparison of vegetation and nonvegetation records, we (4) attempt to identify the point at which humans, rather than climate, became the dominant force driving regional vegetation composition.

\section{Study area}

The monsoonal regions of central Asia covered in this study $\left(70^{\circ} \mathrm{E}-\right.$ $130^{\circ} \mathrm{E}, 20^{\circ} \mathrm{N}-50^{\circ} \mathrm{N}$ ) encompass most parts of China, Mongolia, northern India and Kyrgyzstan (Fig. 1). Due to the large latitudinal and altitudinal extents, various climatic (from tropical to subpolar, and high-cold alpine zones) and vegetation zones (from tropical rain forest to boreal evergreen forest, together with desert and alpine tundra) are represented within the study area. Located towards the eastern margin of the Eurasian continent, the climates of northern India, southwest China and eastern China are influenced by monsoon activity, having warm, humid summers coupled with cold, dry winters. Towards the west, there is a strengthening of continental conditions while the semi-arid and arid areas of northwestern China are dominated by westerly circulation.

\section{Materials and methods}

\subsection{Selection of palaeoclimatic records}

A large number of palaeoclimatic records from monsoonal central Asia have been published during the last two decades. However there is a large disparity in sample resolution and age control. To ensure sufficient data quality, all records included in our analyses were required to meet the following criteria:

1) Analysed proxies should be indicative of moisture and/or temperature change.

2) Records should provide continuous information for at least 4000 years since 18 cal. kyr BP.

3 ) The sequences should be constructed using a reliable chronology, with at least four dating control points during the Holocene.

4) Sequences should have a sufficient resolution $(<200$ years for the Holocene period).

Due to the low information density from Mongolia, Inner Mongolia and northwest China, ten records with less dating control points or lower resolution were also included in our data set. 92 records (40 pollen records and 52 non-pollen records) from 72 sites were selected for this study (see detailed information and locations in Table 1 and Fig. 2a). Non-pollen records are based on various proxies including geophysical (lithological description, color index, grain size, magnetic susceptibility etc.), geochemical (organic and inorganic carbon content, stable carbon and oxygen isotope ratios, elemental composition) and biological data (diatoms, ostracods and chironomidae). It is still debated whether isotopic records from ice cores reflect temperature change or local moisture evolution. As such, we didn't use these records for moisture reconstruction (e.g. Dunde, Thompson et al., 1990; Guliya, Thompson et al., 1997). Due to the differing nature of various climate archives, it is impossible to consistently translate each individual proxy into semi-quantitative climate signals at all sites. Therefore, after initially crosschecking the plausibility of their interpretations, we largely agreed with the original conclusions reached by the authors when classifying proxy-based climatic 
Table 1

Palaeoclimatic records from Central Asia arranged from south to north (abbreviations see below).

\begin{tabular}{|c|c|c|c|c|c|c|c|c|c|c|c|c|c|c|c|c|}
\hline \multirow[t]{2}{*}{ No. } & \multirow[t]{2}{*}{ Section } & \multirow{2}{*}{$\begin{array}{l}\mathrm{N} \\
\left({ }^{\circ}\right)\end{array}$} & \multirow{2}{*}{$\begin{array}{l}\mathrm{E} \\
\left({ }^{\circ}\right)\end{array}$} & \multirow{2}{*}{$\begin{array}{l}\text { Eleva. } \\
\text { (m a.s.l.) }\end{array}$} & \multirow[t]{2}{*}{ Archive } & \multirow{2}{*}{$\begin{array}{l}\text { Time } \\
\text { (cal. kyr BP) }\end{array}$} & \multirow{2}{*}{$\begin{array}{l}\text { Resol. } \\
\text { (yr) }\end{array}$} & \multicolumn{7}{|c|}{ Dating $^{\mathrm{a}}$} & \multirow[t]{2}{*}{ Methods ${ }^{\mathrm{b}}$} & \multirow[t]{2}{*}{ Reference } \\
\hline & & & & & & & & No. & method & A & B & c & D & E & & \\
\hline R1 & Qilu Hu & 24.18 & 102.75 & 1797 & Lake & $50.0-0$ & 180 & 16 & AMS ${ }^{14} \mathrm{C}$ & 2 & 3 & 4 & 2 & 2 & S O C dO G MS & Hodell et al. (1999) \\
\hline R2 & Xingyun Hu & 24.33 & 102.76 & 1723 & Lake & $25.0-0$ & $\sim 90$ & 14 & AMS ${ }^{14} \mathrm{C}$ & 1 & 1 & 4 & 2 & 2 & $\mathrm{~S} \overline{\mathrm{OC}} \mathrm{dO} \overline{\mathrm{G} \mathrm{MS}}$ & Hodell et al. (1999) \\
\hline R3 & Xiangshui Cave & 25.15 & 110.55 & 400 & Stalagmite & $6.0-0$ & $\sim 75$ & 4 & $\mathrm{Th} / \mathrm{U}$ & 1 & 1 & - & - & 3 & $\mathrm{~d} \overline{\mathrm{OdC}}$ & Zhang et al. (2004) \\
\hline R4 & Dongge Cave & 25.32 & 108.09 & 680 & Stalagmite & $16.0-0$ & $1 \sim 15$ & 44 & $\mathrm{Th} / \mathrm{U}$ & 1 & 1 & - & - & 1 & $\overline{\mathrm{dO}}$ & Dykoski et al. (2005) \\
\hline R5 & Erhai & 25.75 & 100.25 & 1974 & Lake & $12.9-0$ & $\sim 80$ & 11 & AMS ${ }^{14} \mathrm{C}$ & 2 & 2 & 1 & 4 & 1 & $\overline{\mathrm{SMS} P}$ & Shen et al. (2006) \\
\hline R6 & Didwana Salt lake & 27.33 & 74.58 & n.d. & Salt Lake & $>15.0-0$ & n.d. & 6 & ${ }^{14} \mathrm{C}$ & 2 & 2 & 4 & 3 & 3 & $S \bar{P}$ & Singh et al. (1990) \\
\hline R7 & Lake Shayema & 28.50 & 102.00 & 2400 & Lake & $12.8-0$ & $\sim 100$ & 5 & ${ }^{14} \mathrm{C}$ & 2 & 2 & 4 & 2 & 3 & $S \bar{P} O$ & Jarvis (1993) \\
\hline R8 & Lunkaransar & 28.50 & 73.75 & n.d. & Dry Lake & $10.7-0$ & $\sim 50$ & 15 & ${ }^{14} \mathrm{C}$ & 1 & 2 & 4 & 2 & 3 & $s \bar{X} \mathrm{dCC} G$ & Enzel et al. (1999) \\
\hline R9 & Chen Co & 28.95 & 90.55 & 4420 & Lake Terrace & $10-3.7$ & n.d. & 8 & AMS ${ }^{14} \mathrm{C}$ & 1 & 1 & 3 & 4 & 2 & $\mathrm{SO} \overline{\mathrm{C} / \mathrm{NPG}} \mathrm{CE}$ & Zhu et al. (2009) \\
\hline R10 & Linhua Cave & 29.48 & 109.54 & 455 & Stalagmite & $6.6-0$ & $<10$ & 10 & $\mathrm{U} / \mathrm{Th}$ & 1 & 1 & - & - & 2 & $x \overline{d O d C}$ & Cosford et al. (2008) \\
\hline R11 & Hidden Lake & 29.81 & 92.54 & 4980 & Lake & $13.45-0$ & $\sim 100$ & 7 & AMS ${ }^{14} \mathrm{C}$ & 2 & 2 & 1 & 4 & 3 & $\mathrm{P}-$ & Tang et al. (2000) \\
\hline R12 & Heshang Cave & 30.45 & 110.42 & 294 & Stalagmite & $9.5-0$ & $<10$ & 21 & $\mathrm{Th} / \mathrm{U}$ & 1 & 1 & - & - & 2 & $\overline{\mathrm{d} O} \mathrm{dC}$ & Hu et al. (2008) \\
\hline R13 & Ren Co & 30.73 & 96.69 & 4450 & Lake & $19.6-0$ & 300 & 7 & AMS ${ }^{14} \mathrm{C}$ & 2 & 2 & 1 & 4 & 3 & $P$ & Tang et al. (2000) \\
\hline R14 & Nam Co & 30.75 & 90.50 & 4718 & Lake & $8.4-0$ & $\sim 25-250$ & 12 & AMS ${ }^{14} \mathrm{C}$ & 1 & 1 & 3 & 4 & 2 & $\overline{\mathrm{G}} \mathrm{CM}$ E X O B C/N & Zhu et al. (2008) \\
\hline R15 & Gujjar Hut & 30.90 & 78.80 & $\sim 3500$ & Peat & $7.8-0$ & $\sim 450$ & 3 & ${ }^{14} \mathrm{C}$ & 1 & 1 & 1 & 4 & 3 & $\overline{\text { S MS P }}$ & Phadtare (2000) \\
\hline R16 & Lake Naleng & 31.10 & 99.75 & 4200 & Lake & $17.6-0$ & $<100$ & 11 & AMS ${ }^{14} \mathrm{C}$ & 2 & 3 & 3 & 1 & 2 & $S \bar{P}$ & (Kramer et al., 2009a,b) \\
\hline R17 & Co Ngion & 31.50 & 91.50 & 4515 & Lake & $5.8-0$ & $\sim 100$ & 12 & AMS ${ }^{14} \mathrm{C}$ & 1 & 1 & 3 & 4 & 2 & $\mathrm{P} \overline{\mathrm{O} C M}$ & Shen et al. (2008) \\
\hline R18 & Cuoe Lake & 31.50 & 91.50 & 4532 & Lake & $10.5-1.6$ & n.d. & 13 & AMS ${ }^{14} \mathrm{C}$ & 1 & 1 & 3 & 3 & 1 & $\overline{\mathrm{SGOdC} E C / N}$ & Wu et al. (2006) \\
\hline R19 & Dajiu Lake & 31.5 & 110 & 1700 & Lake Basin & $14.6-0$ & $\sim 80$ & 7 & ${ }^{14} \mathrm{C}$ & 1 & 2 & 4 & 4 & 3 & $S \bar{P}$ & Liu et al. (2001) \\
\hline R20 & Ahung Co & 31.62 & 92.06 & 4575 & Lake & $9.5-4$ & $<50$ & 62 & AMS ${ }^{14} \mathrm{C}$ & 1 & 1 & 3 & 3 & 1 & $\mathrm{C} \overline{\mathrm{O}} \mathrm{dC} \mathrm{dO} / \mathrm{NM} X \mathrm{~S}$ & Morrill et al. (2006) \\
\hline R21 & Shanbao Cave & 31.66 & 110.43 & n.d. & Stalagmite & $11.6-2.0$ & $\sim 40$ & 14 & $\mathrm{U} / \mathrm{Th}$ & 1 & 1 & - & - & 2 & $\mathrm{dO}$ & Shao et al. (2006) \\
\hline R22 & Siling Co & 31.75 & 89.00 & 4500 & Lake & $15.5-0$ & $\sim 200$ & 7 & ${ }^{14} \mathrm{C}$ & 2 & 2 & 4 & 4 & 3 & $\overline{\mathrm{Cd} O \mathrm{dC}}$ & Morinaga et al. (1993) \\
\hline R23 & Zigetang Lake & 32.00 & 90.90 & 4560 & Lake & $10.6-0$ & n.d. & 5 & AMS ${ }^{14} \mathrm{C}$ & 2 & 2 & 3 & 1 & 2 & $\overline{\mathrm{COdC}}$ & Y.H. Wu et al. (2007) \\
\hline R24 & Zigetang Lake & 32.00 & 90.90 & 4560 & Lake & $10.8-0$ & $\sim 170$ & 5 & ${ }^{14} \mathrm{C}$ & 2 & 2 & 3 & 1 & 2 & $\overline{\mathrm{P}}$ & Herzschuh et al. (2006) \\
\hline R25 & Hongyuan & 32.75 & 102.50 & 3466 & Peat & $13.0-0$ & $15-30$ & 17 & AMS ${ }^{14} \mathrm{C}$ & 1 & 1 & 1 & 2 & 2 & $\overline{\mathrm{C}} \mathrm{Co}_{0}$ & Zhou et al. (2002) \\
\hline R26 & Hongyuan No.1 & 32.75 & 102.50 & 3466 & Peat & $11.8-0$ & $\sim 30$ & 15 & AMS ${ }^{14} \mathrm{C}$ & 1 & 1 & 1 & 4 & 3 & $\overline{\mathrm{OdC}}$ & Wang et al. (2004) \\
\hline R27 & No.2 pit & 32.85 & 103.60 & 3492 & Peat & $14.9-0$ & n.d. & 9 & ${ }^{14} \mathrm{C}$ & 1 & 2 & 1 & 4 & 3 & $\overline{\mathrm{PdC}}$ & Yan et al. (1999) \\
\hline R28 & Waqie & 33.08 & 102.75 & n.d. & Profile & $\sim 30.0-0$ & n.d. & 13 & AMS ${ }^{14} \mathrm{C}$ & 1 & 3 & - & - & 3 & $\overline{\mathrm{S}}$ & Zhou et al. (2001) \\
\hline R29 & Tso Kar & 33.16 & 78.00 & 4527 & Lake & $15.2-0$ & n.d. & 32 & AMS ${ }^{14} \mathrm{C}$ & 1 & 1 & 3 & 1 & 2 & SP & Demske et al. (2009) \\
\hline R30 & Bangong Lake & 33.67 & 79.00 & 4241 & Lake & $11.3-0$ & $\sim 100$ & 35 & ${ }^{14} \mathrm{C}, \mathrm{U} / \mathrm{Th}$ & 1 & 1 & 3 & 4 & 1 & $\mathrm{~d} \overline{\mathrm{C}} \mathrm{dO} C \mathrm{X}$ & Fontes et al. (1996) \\
\hline R31 & Bangong Lake & 33.67 & 79.00 & 4241 & Lake & $11.3-0$ & $\sim 100$ & 35 & ${ }^{14} \mathrm{C}, \mathrm{U} / \mathrm{Th}$ & 1 & 1 & 3 & 4 & 1 & $\overline{\mathrm{P}}$ & Campo et al. (1996) \\
\hline R32 & Koucha Lake & 34.00 & 97.20 & 4540 & Lake & $16.4-0$ & $150-600$ & 5 & AMS ${ }^{14} \mathrm{C}$ & 2 & 2 & 4 & 4 & 3 & $\overline{\mathrm{P}}$ & Herzschuh et al. (2009) \\
\hline R33 & Koucha Lake & 34.01 & 97.24 & 4530 & Lake & $16.3-0$ & $80-200$ & 5 & AMS ${ }^{14} \mathrm{C}$ & 2 & 2 & 4 & 4 & 3 & $\overline{\mathrm{S}} \mathrm{XOC \textrm {dC }}$ dO Os M E & Mischke et al. (2008) \\
\hline R34 & Sumxi Co & 34.60 & 80.25 & 5058 & Lake & $15.1-0$ & n.d. & 6 & ${ }^{14} \mathrm{C}$ & 2 & 2 & 1 & 4 & 3 & $\mathrm{M} \mathrm{dC}$ dO Os D O & Gasse et al. (1991) \\
\hline R35 & Sumxi Co & 34.60 & 80.25 & 5058 & Lake & $15.1-0$ & n.d. & 6 & ${ }^{14} \mathrm{C}$ & 2 & 2 & 1 & 4 & 3 & $\overline{\mathrm{P}}$ & Gasse et al. (1991) \\
\hline R36 & Yaoxian & 34.89 & 108.75 & n.d. & Loess & $>8.4-0$ & n.d. & 19 & OSL & 1 & 1 & - & - & 3 & $\overline{\mathrm{S}} \mathrm{MS}$ & H. Zhao et al. (2007) \\
\hline R37 & Yaoxian & 34.93 & 108.83 & n.d. & Loess & $12.0-0$ & $\sim 120$ & 2 & $\mathrm{TL}$ & 2 & 2 & - & - & 3 & $S \bar{P}$ & Li et al. (2003) \\
\hline R38 & Lake Kuhai & 35.30 & 99.20 & 4150 & Lake & $18.0-0$ & 200 & 17 & AMS ${ }^{14} \mathrm{C}$ & 1 & - & 2 & 2 & 4 & $S \bar{P}$ & Wischnewski et al. (2010) \\
\hline R39 & Duowa & 35.41 & 101.95 & 2000 & Loess & $12.5-0.8$ & $\sim 140$ & 19 & OSL & - & - & - & - & 4 & S $\bar{M} S$ G & Maher and $\mathrm{Hu}(2006)$ \\
\hline R40 & Kusai Lake & 35.72 & 92.92 & 4475 & Lake & $3.9-0$ & $\sim 15$ & 7 & AMS ${ }^{14} \mathrm{C}$ & 1 & 1 & 3 & 1 & 2 & $\mathrm{O} \overline{\mathrm{GC} / \mathrm{N}}$ & (Y.B. Wang et al., 2008) \\
\hline R41 & Majiawan & 36.00 & 108.16 & 1400 & Loess & $11.5-0$ & $\sim 100$ & 3 & OSL & 2 & 2 & - & - & 3 & $\overline{G C O M S E S}$ & Huang et al. (2004) \\
\hline R42 & Xiaogou & 36.00 & 105.00 & $\sim 2000$ & Profile & $\sim 25.0-0$ & $\sim 300$ & 18 & AMS ${ }^{14} \mathrm{C}$ & 2 & 2 & 4 & 4 & 3 & SP & Wu et al. (2009) \\
\hline R43 & Chaka Salt Lake & 36.70 & 99.15 & 3200 & Salt Lake & $17.2-0$ & $\sim 350$ & 10 & AMS ${ }^{14} \mathrm{C}$ & 1 & 2 & 3 & 2 & 2 & $S \bar{M} O$ & Liu et al. (2008a) \\
\hline R44 & Qinghai Lake & 37.00 & 100.00 & 3200 & Lake & $18.0-0$ & n.d. & 10 & AMS ${ }^{14} \mathrm{C}$ & 2 & 2 & 3 & 2 & 4 & $\mathrm{Os \textrm {dO }}$ & Liu et al. (2007) \\
\hline R45 & Qinghai Lake & 37.00 & 100.00 & 3200 & Lake & $18.0-0$ & $20-40$ & 6 & AMS ${ }^{14} \mathrm{C}$ & 2 & 2 & 3 & 2 & 3 & $\mathrm{P}-$ & (X.Q. Liu et al., 2002) \\
\hline R46 & Hurleg Lake & 37.32 & 96.90 & 2817 & Lake & $14.0-0$ & $\sim 160$ & 7 & AMS ${ }^{14} \mathrm{C}$ & 2 & 2 & 1 & 4 & 2 & $\overline{\mathrm{P}} \mathrm{CO}$ & Y. Zhao et al. (2007) \\
\hline R47 & Haxi section & 37.50 & 102.40 & 2450 & Profile & $10.9-0$ & 70 & 5 & ${ }^{14} \mathrm{C}$ & 2 & 2 & 4 & 4 & 3 & $\overline{\mathrm{SMS}}$ OC & Wu et al. (1998) \\
\hline
\end{tabular}




\begin{tabular}{|c|c|c|c|c|c|c|c|c|c|c|c|c|c|c|c|c|}
\hline R48 & Jingbian & 37.50 & 109.00 & n.d. & Trench Section & $10.0-0$ & $\sim 100$ & 11 & AMS ${ }^{14} \mathrm{C}$ & 1 & 1 & - & - & 3 & S GC & Xiao et al. (2002) \\
\hline R49 & Midiwan & 37.65 & 108.62 & 1400 & Peat & $15.4-0$ & $\sim 100$ & 23 & ${ }^{14} \mathrm{C}$ & 1 & 1 & 1 & 3 & 2 & $S \overline{P O} d C$ & Zhou et al. (1996) \\
\hline R50 & Dunde & 38.10 & 92.40 & 5325 & Ice Core & $4.55-0$ & $\sim 100$ & - & ice counting & - & - & - & - & - & $\mathrm{d} \overline{\mathrm{O}}$ & Yao and Thompson (1992) \\
\hline R51 & Dunde & 38.10 & 92.40 & 5325 & Ice Core & $11.0-0$ & $1 \sim 1000$ & - & - & - & - & - & - & - & $\overline{\mathrm{P}}$ & Liu et al. (1998) \\
\hline R52 & Hongshui-River section & 38.16 & 102.76 & 1460 & Profile & $8.5-3.2$ & $\sim 50$ & 9 & AMS ${ }^{14} \mathrm{C}$ & - & - & - & - & 4 & $\overline{\mathrm{S}} \mathrm{P}$ & Ma et al. (2004) \\
\hline R53 & Lake Zhuyeze & 39.00 & 103.33 & 1320 & Dry Lake & $11.6-0$ & $\sim 50$ & $12(8)$ & AMS ${ }^{14} \mathrm{C}$ & 1 & 2 & 3 & 2 & 3 & SÖP & Chen et al. (2006) \\
\hline R54 & Qingtu Lake & 39.05 & 103.67 & 1309 & Dry Lake & $11.3-0$ & 40 & 6 & AMS ${ }^{14} \mathrm{C}$ & 1 & 1 & 4 & 4 & 3 & $S \bar{G}$ & Zhao et al. (2003) \\
\hline R55 & Baahar Nuur & 39.10 & 109.20 & 1450 & Salt Lake & $>13.8-0$ & $\sim 50$ & 6 & AMS ${ }^{14} \mathrm{C}$ & 2 & 2 & 4 & 4 & 3 & $S$ MS G C & Feng et al. (2005) \\
\hline R56 & Lake Kichikol & 39.99 & 73.55 & 2541 & Lake & $6.3-0$ & $\sim 90$ & $4(3)$ & AMS ${ }^{14} \mathrm{C}$ & 2 & 2 & 1 & 4 & 2 & $\mathrm{SChOC}$ & Beer et al. (2007) \\
\hline R57 & Lake Kichikol & 39.99 & 73.55 & 2541 & Lake & $6.3-0$ & $\sim 90$ & $4(3)$ & AMS ${ }^{14} \mathrm{C}$ & 2 & 2 & 1 & 4 & 2 & $\mathrm{P}$ & Beer et al. (2007) \\
\hline R58 & Lake Yanhaizi & 40.15 & 108.45 & 1180 & Lake & $>15.0-0$ & $\sim 100$ & 10 & AMS ${ }^{14} \mathrm{C}$ & 2 & 2 & 3 & 2 & 2 & $\overline{\mathrm{S}} \mathrm{CO} / \mathrm{C} / \mathrm{N}$ E M X MS & Chen et al. (2003) \\
\hline R59 & Daihai Lake & 40.55 & 112.75 & 1221 & Lake & $11.2-0$ & $15-77$ & 8 & AMS ${ }^{14 C}$ & 1 & 1 & 2 & 1 & 2 & CO & Xiao et al. (2006) \\
\hline R60 & Daihai Lake & 40.55 & 112.75 & 1230 & Lake & $11.2-1$ & $30-150$ & 8 & AMS ${ }^{14} \mathrm{C}$ & 1 & 1 & 2 & 1 & 2 & $\overline{\mathrm{SP}}$ & Xiao et al. (2004) \\
\hline R61 & Chasuqi & 40.67 & 111.12 & n.d. & Lake & $10.2-0$ & $\sim 80$ & 4 & ${ }^{14} \mathrm{C}$ & 3 & 4 & 4 & 4 & 3 & $\mathrm{P}^{-}$ & Wang et al. (1997) \\
\hline R62 & Diaojiao Lake & 41.30 & 112.35 & 1800 & Lake & $9.6-0$ & $\sim 100$ & 4 & AMS ${ }^{14} \mathrm{C}$ & 2 & 2 & 4 & 4 & 3 & $\overline{\mathrm{P}}$ & Shi and Song (2003) \\
\hline R63 & Bayanchagan Lake & 41.65 & 115.21 & 1355 & Lake & $12.5-0$ & $<150$ & 9 & AMS ${ }^{14} \mathrm{C}$ & 1 & 2 & 3 & 3 & 2 & $\overline{\mathrm{P}}$ & Jiang et al. (2006) \\
\hline R64 & Lake Eastern Juyanze & 41.83 & 101.63 & n.d. & Profile & $5.3-2.8$ & $3-70$ & 4 & AMS ${ }^{14} \mathrm{C}$ & 1 & 1 & 4 & 4 & 3 & $\bar{O}$ s E dO dC X P S & Mischke et al. (2005) \\
\hline R65 & Juyan palaeolake & 41.89 & 101.85 & 892 & Palaeolake drill & $10.7-1.7$ & $\sim 150$ & 5 & AMS ${ }^{14} \mathrm{C}$ & 1 & 1 & - & 4 & 3 & $\overline{\mathrm{SP}}-$ & Herzschuh et al. (2004) \\
\hline R66 & Bosten Lake & 41.94 & 86.76 & 1048 & Lake & $8.6-0$ & $\sim 20$ & 11 & $\mathrm{AMS}^{14} \mathrm{C}$ & 2 & 2 & 1 & 4 & 1 & $O \mathrm{~S}^{-} \mathrm{dC} \mathrm{dO}$ & Mischke and Wünennmann (2006) \\
\hline R67 & Bosten Lake & 42.00 & 87.00 & 1048 & Lake & $8.0-0$ & $\sim 100$ & 5 & $\mathrm{AMS}^{14} \mathrm{C}$, OSL & 2 & 2 & 3 & 3 & 2 & SGP & Huang et al. (2009) \\
\hline R68 & Hani Peat Bog & 42.21 & 126.21 & 900 & Peat & $12.3-0$ & $\sim 20$ & 10 & AMS ${ }^{14} \mathrm{C}$ & 1 & 1 & 1 & 4 & 3 & $\mathrm{dC}^{-}$ & Hong et al. (2005) \\
\hline R69 & Lake Sihailongwan & 42.29 & 126.60 & 797 & Lake & $15.3-0$ & $\sim 1$ & 36 & AMS ${ }^{14} \mathrm{C}$ & 1 & 1 & 1 & 1 & 2 & $\overline{O C}$ E lam. P D & Schettler et al. (2006) \\
\hline R70 & Lake Issyk-Kul & 42.50 & 77.00 & 1607 & Lake & $8.7-1.0$ & $\sim 180$ & 16 & AMS ${ }^{14} \mathrm{C}$ & 1 & 1 & 3 & 4 & 2 & $\overline{\mathrm{SOs}} \mathrm{dO} \mathrm{dC} \overline{\mathrm{E}}$ & Ricketts et al. (2001) \\
\hline R71 & Xiaoniuchang & 42.62 & 116.83 & 1460 & ancient lake bed & $10.9-0$ & $\sim 250$ & 3 & AMS ${ }^{14} \mathrm{C}$ & 2 & 2 & - & 4 & 3 & SCGE & H.Y. Liu et al. (2002) \\
\hline R72 & Xiaoniuchang & 42.62 & 116.83 & 1460 & ancient lake bed & $10.9-0$ & $\sim 250$ & 3 & AMS ${ }^{14} \mathrm{C}$ & 2 & 2 & - & 4 & 3 & $\mathrm{P}$ & H.Y. Liu et al. (2002) \\
\hline R73 & Liuzhouwan & 42.71 & 116.67 & 1365 & ancient lake bed & $18.3-0$ & 360 & 3 & AMS ${ }^{14} \mathrm{C}$ & 2 & 3 & 4 & 4 & 3 & $\overline{\mathrm{S}} \mathrm{G} O \mathrm{C} / \mathrm{N}$ P M MS & H.Y. Wang et al. (2001) \\
\hline R74 & Haoluku & 42.96 & 116.75 & 1295 & ancient lake bed & $12.0-0$ & $\sim 220$ & 3 & AMS ${ }^{14} \mathrm{C}$ & 2 & 3 & 4 & 4 & 3 & $\mathrm{~S} \overline{\mathrm{GOC} / \mathrm{N} \mathrm{M} \mathrm{MS}}$ & H.Y. Wang et al. (2001) \\
\hline R75 & Haoluku & 42.96 & 116.75 & 1295 & ancient lake bed & $12.0-0$ & $\sim 220$ & 3 & AMS ${ }^{14} \mathrm{C}$ & 2 & 3 & 4 & 4 & 3 & $\mathrm{P}$ & H.Y. Wang et al. (2001) \\
\hline R76 & Dali Lake & 43.35 & 116.72 & 1226 & Lake & $12.7-0$ & $\sim 20$ & 18 & AMS ${ }^{14 C}$ & 1 & 1 & 3 & 2 & 2 & $\overline{\mathrm{S}} \mathrm{CO}$ & Xiao et al. (2008) \\
\hline R77 & Barkol Lake & 43.70 & 92.85 & 1580 & Lake & $9.4-0$ & 38 & 7 & ${ }^{14} \mathrm{C}$ & 1 & 2 & 3 & 1 & 2 & $S \bar{G}$ & Xue et al. (2008) \\
\hline R78 & Lake Manas & 45.75 & 86.00 & 251 & Lake & $11.6-0$ & $\sim 150$ & 8 & $\mathrm{AMS}^{14 \mathrm{C}}$ & 2 & 2 & 4 & 4 & 3 & $S C M X G \mathrm{dO} d C O D$ & Rhodes et al. (1996) \\
\hline R79 & Lake Manas & 45.75 & 86.00 & 251 & Lake & $11.6-0$ & $\sim 150$ & 8 & $\mathrm{AMS}^{14 \mathrm{C}}$ & 2 & 2 & 4 & 4 & 3 & $\mathrm{P}$ & Rhodes et al. (1996) \\
\hline R80 & Wulungu Lake & 47.00 & 87.50 & 478.6 & Lake & $9.55-0$ & $50-100$ & 7 & $\mathrm{AMS}^{14 \mathrm{C}}$ & 1 & 2 & 3 & 1 & 1 & $\overline{\mathrm{S}} \mathrm{GCC} / \mathrm{N} \mathrm{dCO}$ & Liu et al. (2008b) \\
\hline R81 & Wulungu Lake & 47.00 & 87.50 & 478.6 & Lake & $9.55-0$ & $50-100$ & 7 & $\mathrm{AMS}^{14 \mathrm{C}}$ & 1 & 2 & 3 & 1 & 1 & $\mathrm{P}$ & Liu et al. (2008b) \\
\hline R82 & Hoton-Nur & 48.66 & 88.30 & 2083 & Lake & $>11.5-0$ & $\sim 150$ & $1+6$ & AMS ${ }^{14} \mathrm{C}$ & - & - & - & 4 & 2 & $\overline{\mathrm{D}} \mathrm{S}$ & Rudaya et al. (2009) \\
\hline R83 & Hoton-Nur & 48.66 & 88.30 & 2083 & Lake & $>11.5-0$ & $\sim 150$ & $1+6$ & AMS ${ }^{14} \mathrm{C}$ & - & - & - & 4 & 2 & $\overline{\mathrm{P}}$ & Rudaya et al. (2009) \\
\hline R84 & Lake Telmen & 48.66 & 97.33 & 1789 & Lake & $7.1-0$ & & 8 & AMS ${ }^{14} \mathrm{C}$ & 1 & 1 & 1 & 1 & 2 & $\overline{\bar{S}}$ X D P lam. & Peck et al. (2002) \\
\hline R85 & Lake Telmen & 48.66 & 97.33 & 1789 & Lake & $7.0-0$ & $\sim 200$ & 6 & AMS ${ }^{14} \mathrm{C}$ & 1 & 1 & 1 & 1 & 2 & $\bar{S} P-$ & Fowell et al. (2003) \\
\hline R86 & Hulun Lake & 49.00 & 117.00 & 545 & Lake Profile & $15.8-0$ & $\sim 150$ & 10 & ${ }^{14} \mathrm{C}$ & 1 & 1 & 1 & 4 & 3 & $S \bar{D}$ & Xue et al. (2003) \\
\hline R87 & Gun Nuur & 50.25 & 106.60 & 600 & Lake & $12.2-0$ & 300 & 7 & ${ }^{14} \mathrm{C}$ & 1 & 2 & 4 & 4 & 3 & SP & Dorofeyuk and Tarasov (1998) \\
\hline R88 & Gun Nuur & 50.42 & 106.10 & 600 & Lake & $9.4-0$ & $\sim 30$ & 9 & AMS ${ }^{14} \mathrm{C}$ & 1 & 1 & 3 & 4 & 3 & $\mathrm{~S} \overline{\mathrm{D}} \mathrm{CO} \mathrm{dC} \mathrm{MS}$ & Feng et al. (2005) \\
\hline R89 & Hovsgol Lake & 50.54 & 101.16 & 1645 & Lake & $18.0-0$ & & 11 & AMS ${ }^{14} \mathrm{C}$ & 2 & 2 & 1 & 2 & 2 & $\mathrm{SEOCM}$ & Murakami et al. (2009) \\
\hline R90 & Hovsgol Lake & 50.54 & 101.16 & 1645 & Lake & $7.1-0$ & 450 & 2 & ${ }^{14} \mathrm{C}$ & 2 & 2 & 4 & 4 & 3 & $s \overline{\mathrm{P}}$ & Dorofeyuk and Tarasov (1998) \\
\hline R91 & Dood Nuur & 51.33 & 99.39 & 1538 & Lake & $14.4-0$ & $\sim 700$ & 2 & ${ }^{14} \mathrm{C}$ & 4 & 4 & 4 & 2 & 3 & $S \bar{D}$ & Dorofeyuk and Tarasov (1998) \\
\hline R92 & Dood Nuur & 51.33 & 99.39 & 1538 & Lake & $14.4-0$ & $\sim 700$ & 2 & ${ }^{14} \mathrm{C}$ & 4 & 4 & 4 & 2 & 3 & $S \bar{P}$ & Dorofeyuk and Tarasov (1998) \\
\hline
\end{tabular}

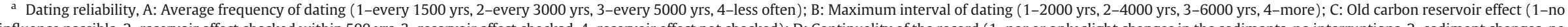

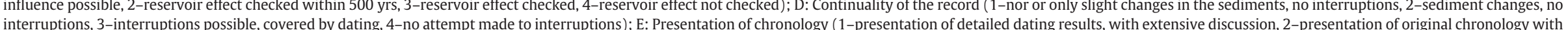
interruptions, 3-interruptions possible, covered by dating, 4-no attempt made to interruptions);

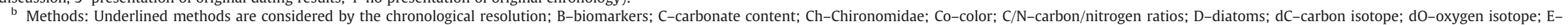
elements; G-grain size; lam.-laminations; M-minerals; Mo-mollusks; MS-magnetic susceptibility; O-organic content; Os-Ostracod; P-pollen; S-sediment description; X-X ray diffraction. 
inferences from the records. Only ten records span the complete period between 18 and 0 cal. kyr BP. About 90\% (84 sites) of the records cover at least $7000{ }^{14} \mathrm{C}$ years. With the exception of 11 records from stalagmites, loess or ice cores that were dated by means of $U / T h$, OSL or TL, all sequences were dated using radiocarbon methods, mostly AMS ${ }^{14} \mathrm{C}$ dating. Most authors provided the original ${ }^{14} \mathrm{C}$ data, allowing us the opportunity to consistently re-establish age-depth relationships for all records. Following a correction for the 'reservoir effect' (necessary for 28 sites), all ${ }^{14} \mathrm{C}$ ages were computed to calendar ages using Calib 5.0.1 software and the 'IntCal04' database (Reimer et al., 2004). All ages in this text are given as calibrated ages with the notation 'cal. yr BP'. With the exception of 9 records from areas containing very few records, most sequences have a resolution of less than 200 years, which sometimes extends as far as decadal resolution (Table 1). In order to later evaluate the relationship between pollen and non-pollen records, sites with both pollen and non-pollen sequences were treated as two separate records. In cases where several records (both pollen and non-pollen) have been published from the same site (e.g. Qinghai Lake: two pollen records (X.Q. Liu et al., 2002; Shen et al., 2005) and more than five non-pollen records (Lister et al., 1991; Ji et al., 2005; Shen et al., 2005; Liu et al., 2007; Ji et al., 2009)), all individual records were evaluated during an initial screening step. Due to the consistency of the climatic inferences, we decided to include only the most recent record in our analyses.

In order to further examine sub-regional patterns in climate signals, we assigned our records to three sub-regions namely the area outside of the present monsoon boundary, the ISM area and the EASM area (Fig. 2a). Owing to the fact that there is no definitive spatial boundary between the EASM and ISM, the definitions of sub-regions used here are based on the current understanding of monsoonal systems despite the fact that this is subject to change.

\subsection{Inferences of moisture and warmth indices for palaeoclimatic records}

We translated the moisture (temperature) signals from the separate studies into a moisture (warmth) index of a five-part scale $(-2,-1,0,+1,+2)$ : the lowest value $(-2)$ indicates the driest (coldest) intervals for each site since $18 \mathrm{cal}$. kyr BP while the maximum $(+2)$ indicates the wettest (warmest) periods, (0) indicates that climatic conditions were similar to present. The justification for designating an ordinal moisture (warmth) scale is that each individual site may not be linearly comparable to others due to differences in geographic location, archives, proxies used and sensitivity. Moreover, owing to the qualitative nature of the palaeoclimatic records, it is impossible to translate this information on a finer climatic scale. The moisture (warmth) scales are relative, in a semi-quantitative sense and are only applicable to each individual site (Chen et al., 2008; Zhao et al., 2009). Relative moisture (warmth) sequences were constructed for each 100-year interval during Holocene period (12-0 cal. kyr BP), and for each 200-year interval before the Holocene (18-12 cal. kyr BP).

Mean moisture index values for selected time slices were mapped using a Kriging interpolation model in the ArcGIS 9.2 program (Johnston et al., 2001).

\subsection{Mapping and ordination of palaeomoisture index results}

Ordination techniques are powerful tools to assess underlying patterns in large data sets. However, due to the low number of temperature records and the lack of sufficient moisture records before 10 cal. kyr BP, numerical analyses were performed only on 65 moisture sequences spanning the last $10 \mathrm{cal}$. kyr, including 15 pollen and 50 nonpollen based records. Almost $25 \%$ of the records (19 counts) don't quite cover the whole period and contain gaps, usually of less than thousand years. To avoid subsequent biases, missing data was generally replaced with mean values from the nearest three sites when available; such mean values were also standardized to our five-part scale (e.g. Ahung Co, Morrill et al., 2006; Nam Co, Zhu et al., 2008).

To examine the underlying patterns of our synthesized climate indices, principal component analysis (PCA) using moisture indices from selected sites as variables and the time slices as observations (data were centered by species without transformation), was performed using CANOCO 4.5 for ordination (ter Braak and Smilauer, 2002). Almost identical results were obtained by non-metric Multidimensional scaling (nmMDS; results not shown) that was processed through the Brodgar 2.5.7 program (Zuur et al., 2007).

To evaluate concordance between pollen and non-pollen based records, Procrustes analysis based on the results of four PCA axes from both pollen and non-pollen records, was performed using the R 2.9.0 Program (Mardia et al., 1979). The significance of the Procrustes fit was tested using 101 random permutations, which were modified to allow restricted permutations for time series data (pers. comm. Gavin Simpson). Correlation using symmetric Procrustes rotation was found to be 0.8399 combined with a significance of 0.009901 (meaning that the permutations failed only once during the calculation).This indicates significant concordance between pollen and non-pollen data sets (Peres-Neto and Jackson, 2001) implying synchronous signals between pollen and non-pollen records on centennial timescales as reported by Seppa and Bennett (2003). This essentially means that Holocene pollen based records are not biased by anthropogenic activity, permitting us to use them together for ordination purposes.

PCA scores of the first two axes were mapped in order to extract regional moisture evolution pattern in Holocene using Kriging interpolation model in ArcGIS 9.2 program (Johnston et al., 2001).

\subsection{Meteorology data of the recent past}

Meteorological data used in this study are obtained from the NCEP/ NCAR reanalysis project. Due to the fact that the reanalysis system and the model used remain unchanged throughout the period, the reanalyzed data provide a reliable database data for studying interannual circulation variability (Kalnay et al., 1996; Kistler et al., 2001). In this study, monthly mean winds (u-wind, v-wind and omega-wind) at standard pressure levels (totally 17 standard levels) from the reanalysis data for the period from January 1979 to December 2008 were used.

The Monsoonal Hadley Index (MH Index), a dynamical index for Indian Summer Monsoon variability defined by Goswami et al. (1999), is calculated as the meridional wind-shear anomaly (between $850 \mathrm{hPa}$ and $200 \mathrm{hPa})$ averaged across the ISM dominated area $\left(70^{\circ} \mathrm{E}-\right.$ $\left.110^{\circ} \mathrm{E}, 10^{\circ} \mathrm{N}-30^{\circ} \mathrm{N}\right)$, expressed as:

$\mathrm{MH}_{\mathrm{ISM}}=\mathrm{V}_{850}^{*}-\mathrm{V}_{200}^{*}$

Where $V_{850}^{*}$ and $V_{200}^{*}$ are the meridional wind anomalies at $850 \mathrm{hPa}$ and $200 \mathrm{hPa}$ respectively, averaged over the summer season (June to August) throughout the defined ISM region. All calculations and maps were computed using Grid Analysis and Display System (GrADS) Version 1.8 (Berman et al., 2001).

\section{Results}

\subsection{Variations in the mean moisture and warmth indices}

In total 40 pollen based and 52 non-pollen based records provide moisture indices from 72 sites, while 18 pollen based and 18 nonpollen based sequences are indicative of changes in warmth. The mean indices for both moisture and warmth during the last $18 \mathrm{cal}$. kyr are shown in Fig. 3. These show near-synchronous changes in pollen and non-pollen records, confirming the previous findings from 

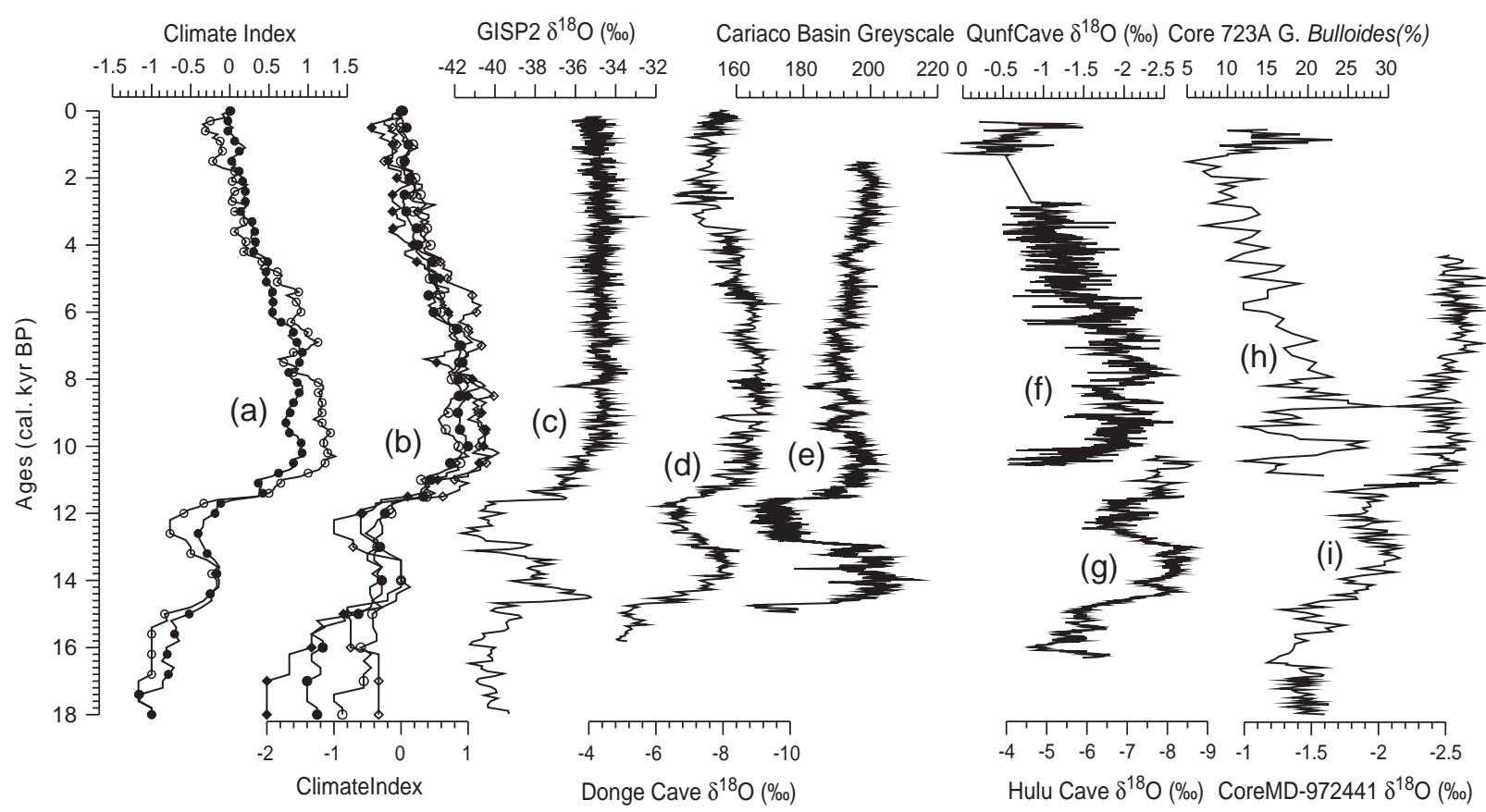

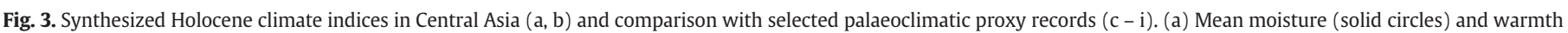

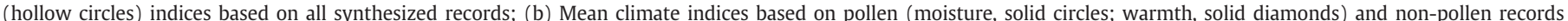

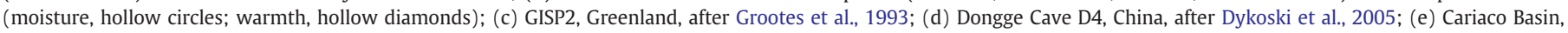

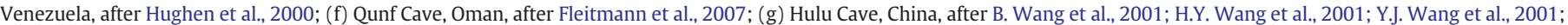
(h) 723A-Core, Arabian Sea, after Gupta et al., 2003; (i) MD972441-Core, Sulu Sea, after Oppo et al., 2003.

Procrustes analyses and outlining the general trends for moisture and warmth evolution over the last $18 \mathrm{cal}$. kyr.

Despite a scarcity of available data for periods prior to $15 \mathrm{cal}$. kyr BP, mostly dry and cold conditions prevailed. Thereafter, a relatively wet and warm period which lasted for 2000 years (synchronous with the Bølling/Allerød period in the north Atlantic region) was followed by a $1500-y r$ dry, cold phase, probably reflecting the Younger Dryas event. At the beginning of Holocene, both moisture levels and temperatures increased abruptly reaching a maximum at around $10 \mathrm{cal}$. kyr BP. The Holocene Optimum lasted until $8 \mathrm{cal}$. kyr BP followed by a trend towards drier and colder conditions, which prevailed until the latter part of the Holocene.

Synthesized moisture indices from three sub-regions (see additional online material, Fig. S1), confirm synchronous increase in moisture availability at the beginning of the Holocene (12-10 cal. kyr $\mathrm{BP})$. However, different trends occurred following the period of maximum moisture. Moisture levels decreased first within the area outside of the present monsoon boundary around 7.5 cal. kyr BP (but with another wet period between 5 and 2 cal. kyr BP); by 6.5 cal. kyr $\mathrm{BP}$ moisture levels had also decreased in the ISM area and by ca. 4.5 cal. kyr BP in the EASM area.

\subsection{Frequency of impacts of anthropogenic activity}

In Fig. 4, we summarize the previous studies within our data set that were judged by the authors to show evidence of anthropogenic impacts. The earliest human influences are described in studies from the Chinese Loess Plateau at 8 cal. kyr BP (Huang et al., 2004). After 6 cal. kyr BP, and especially from 4 cal. kyr BP onwards, evidence for anthropogenic impact increases and reaches a maximum during the last 1000 years (see also in Fig. 6o). Spatial analysis shows that the records of anthropogenic impact centre around southern China and the Chinese Loess Plateau region and, are sparsely distributed throughout northern India, Mongolia, Kyrgyztan and Xinjiang (China) (Fig. 6o).

\subsection{Temporal and spatial analysis of PCA axes scores}

The axes scores from PCA performed on the combined pollen and non-pollen data sets of the last 10 cal. kyr are shown in Fig. 4. The first axis (PC1), accounting for $46.3 \%$ of the total variance, shows relatively high values (ca. 1.5) until 7 cal. kyr BP, then decreases gradually over the following 3000 years to values of -1 . After this, for the last 4000 years, values remain negative. Compared to the relatively steady PC1, the second axis (PC2, accounting for 13.4\%) shows more fluctuations. Following a gentle increase over 3500 years, PC2 reaches a maximum at about 5000 cal. yr BP which lasts for 2000 years, then decreases sharply to negative values of -0.5 in less than 1000 years. Values slightly fluctuated during the last period, illustrating a different temporal pattern from PC1.

The two PCA axes also show distinctive spatial patterns (Fig. 5). PC1 decreases stepwise from south to north i.e. from the highest values in northern India and southwestern China, to the lowest values in Mongolia. PC2, in contrast, shows a more continuous decrease from southeast to northwest, except for two sites from the northeastern part of China which show negative values such as those found in northwestern China and western Mongolia. Additionally, roughly the same results were obtained for the warmth index (not shown), but they were not interpreted due to the low density of data points (only 26 sites available).

Independent PCA analyses of moisture indices since $10 \mathrm{cal}$. kyr BP for three sub-regions (Fig. 4 c,d) present consistent first axis patterns with high values between 10 and $7 \mathrm{cal}$. kyr BP, and a gradual decrease to the present conditions until $4 \mathrm{cal}$. kyr BP. However for the second axis values, the region outside of present monsoon boundary, ISM and EASM areas show strongly differing signals with peaks at 5.5-4 cal. kyr BP, 8-7 cal. kyr BP and 7-4.5 cal. kyr BP respectively. 

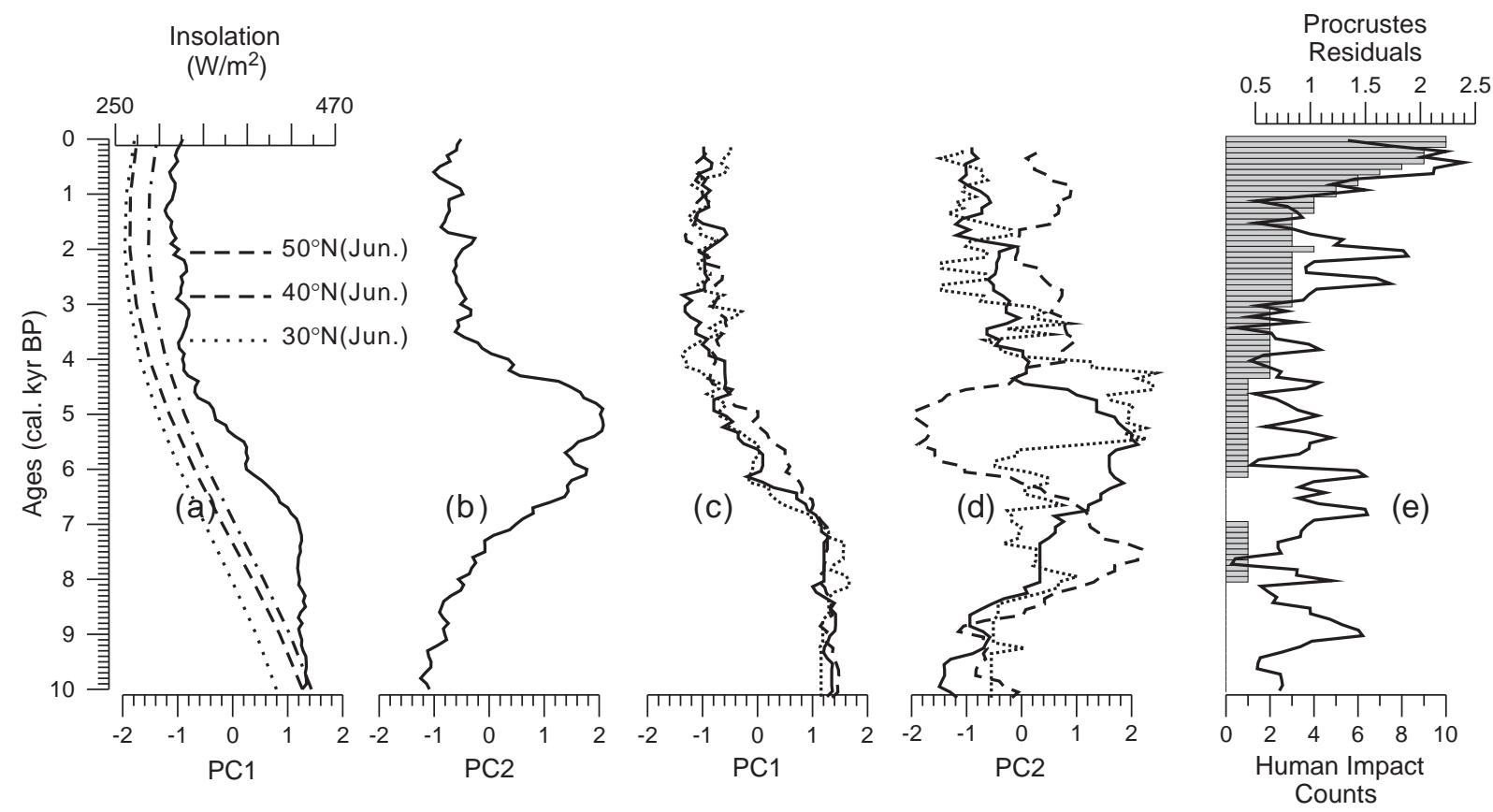

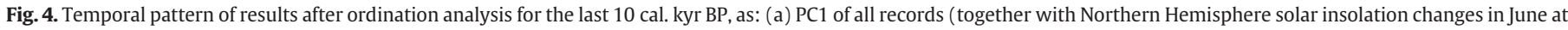

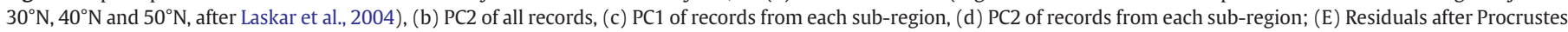

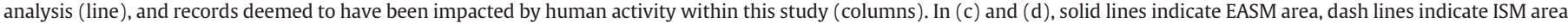
and dot lines indicate the area outside of present monsoon boundary.

\section{Discussion}

5.1. Reliability of climate inferences from proxy records in monsoonal central Asia

Despite taking utmost care in both site selection and methodological approach, the climatic information that we obtained from our meta-analyses faced the following problems:

1) Temporal resolution and age-control of records differ. Generally, records derived from stalagmites have the highest resolution of decadal or even near-annual resolution. As the most common archive, lacustrine sediments from either underwater cores or dry sections vary in resolution from annual to centennial scales.

2) Spatial resolution of our data differs as archives are not evenly distributed across the study area. As shown in Fig. 2, most of our records were obtained from central China, the eastern Tibetan Plateau and Inner Mongolia whilst information from remote areas in northern and western Tibet and from desert areas in northwestern China and Mongolia is sparse due to the lack of available archives.

3) Sensitivity to climate change differs in various proxies. On account of the nonlinear response to climate change, proxy-based moisture and temperature reconstructions all have individual signalresponse relationships. Furthermore, warmth records are probably not as reliable since most proxies are dependent on moisture and encompass a mixture of precipitation and temperature signals (e.g. vegetation changes, lake level fluctuations, stable isotope records, etc.). In addition to this, our assumptions that associations exist between warm and wet conditions and between dry and cold conditions may have artificially biased the climatic inferences.

4) The reliability of climate inferences from glacial flora is limited due to formerly low $\mathrm{CO}_{2}$ concentrations that supported the expansion of drought resistant vegetation which results in an underestimation of moisture levels from pollen records (Cowling and Sykes, 1999; Jackson and Williams, 2004; H. Wu et al., 2007).
5) Since the appearance of civilizations, anthropogenic activity has had an increasingly important impact on climate records and becomes more apparent in records dated since $6000 \mathrm{cal}$. yr BP, and especially since $1000 \mathrm{cal}$. yr BP (Fig. 4). Furthermore the trend of records with an apparent human impact perfectly matches a significant increase in residuals following Procrustes analysis, meaning that the largest difference between pollen and non-pollen based records for the last 1000 years might be caused by the progressive importance of anthropogenic activity which is consistent with the results of Zhao et al. (2009). The main focus of our study has been on climate change whilst exploring the impact of humans was a secondary aim in order to assess the reliability of the climatic inferences. Even though no records in our data set support the transition between human- and climatedriven vegetation changes as suggested by Dearing et al. (2008) based on data from Erhai Lake, the level of continuous human activity has potentially biased the climatic significance of the proxies, especially in central China during the second half of the Holocene.

\subsection{Spatial and temporal climate patterns in monsoonal central Asia} since 18 cal. kyr BP

The main features of the climate history of monsoonal central Asian can be inferred from changes in the mean moisture (warmth) index values (Fig. 3; Fig. S1) and from maps showing spatially interpolated moisture (warmth) index values of selected time slices (Fig. 6).

The majority of the 16 records that were available for the period from 18 to 15 cal. kyr BP reflect dry to moderately dry together with cold to moderately cold conditions throughout China (Fig. 6a, i), yielding minimum mean values for the whole study interval (Fig. 3), indicating that monsoonal central Asian climate in the time immediately after the LGM was characterized by dry and cold conditions. This is in agreement with inferences from high-latitude ice core records (GISP2, Grootes et al., 1993; Stuiver et al., 1995; Vostok, Sowers et al., 1993; Petit et al., 1999) and low-latitude marine 

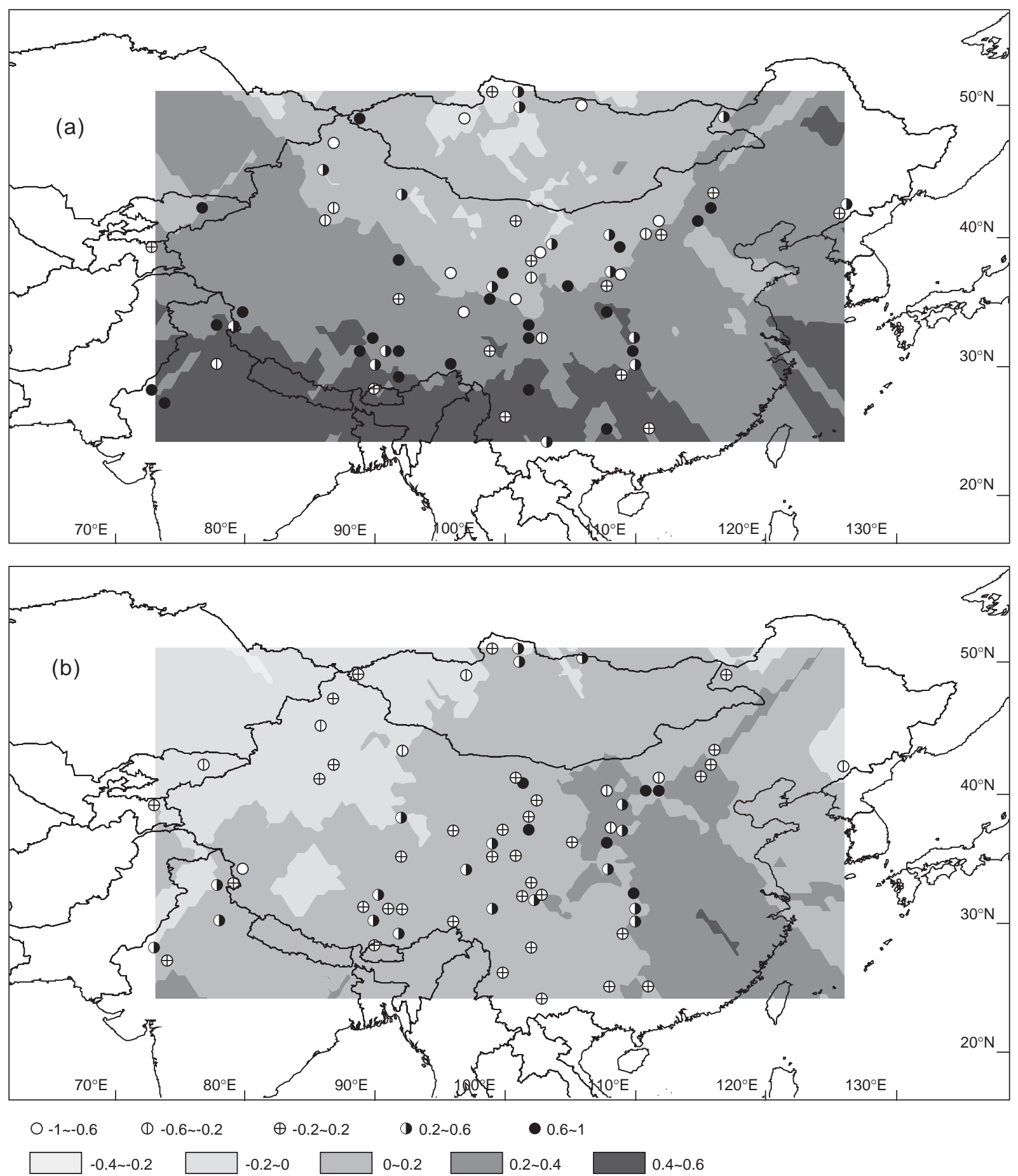

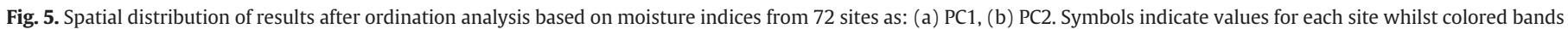
represent interpolated zones through the Kriging model.

records (Arabian Sea, Sonzogni et al., 1998; South China Sea, Wang et al., 1999; Steinke et al., 2001; Sulu Sea, Linsley, 1996; Oppo et al., 2003). However, two sites, namely Chaka salt lake (Qaidam Basin) and Xiaogou section (Chinese Loess Plateau), document abnormally wet conditions (Fig. 6a). The authors inferred that these were related to the reduced evaporation rates during glacial times (Liu et al., 2008a; Wu et al., 2009).

Moderate dry conditions were largely recorded between 15 and 12 cal. kyr BP (Fig. 6b). However, two major climate events are clearly indicated by the mean values. Firstly a warm, wet period culminating at around $14 \mathrm{cal}$. kyr BP is consistent with findings of an initial increase in the Indian Summer Monsoon in the Arabian Sea area (Figs. 3, 6g, j) (Overpeck et al., 1996), which was synchronous with the Bølling/Allerød warm period recognized in European and North Atlantic climate records (Weaver et al., 2003). Secondly, a cold reversal immediately prior to the Holocene apparent in many records (Figs. 3, 6h) is probably related to the Younger Dryas cold event (Dansgaard et al., 1989). However, due to the low number of records available, it is difficult to define chronological control for these events. Using our available data it can only be stated that the Bølling/Allerød 
period was warm and wet and that the Younger Dryas was cold and dry, and that both events occurred in central China, on the western Tibetan Plateau and in northern Mongolia.

(a) $18-15$ cal. kyr BP

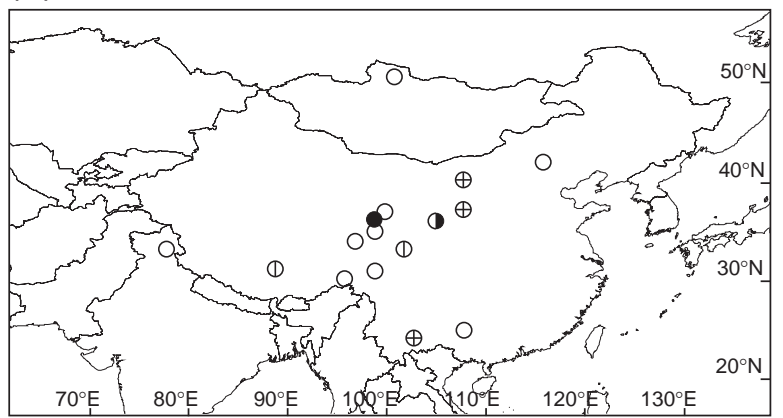

(c) Holocene Transition (12-10 cal. kyr BP)

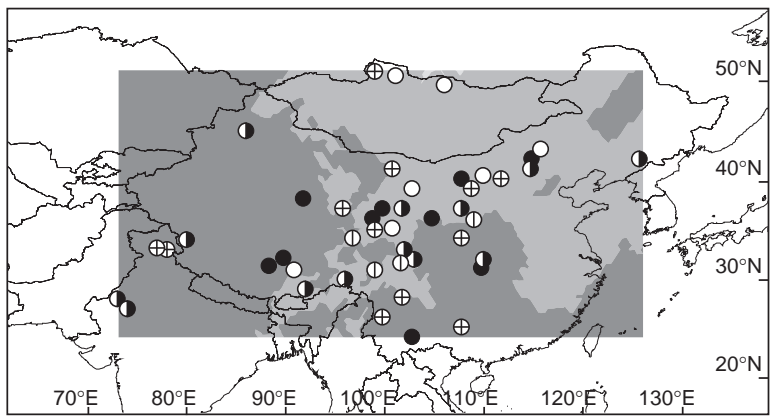

(e)mid Holocene(7-4 cal. kyr BP)

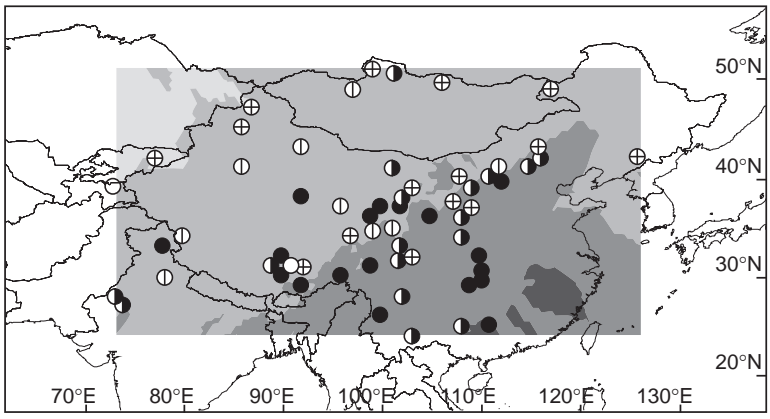

\section{(g)Bølling/Allerød}

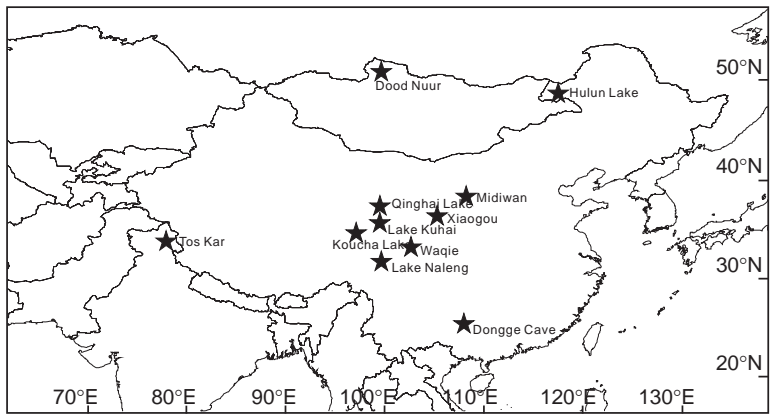

Moisture and warmth increased abruptly and wet conditions prevailed in the western part of our study area at the beginning of the Holocene (Figs. 3 and 6c, k) representing a second enhancement of (b) $15-12$ cal. kyr BP

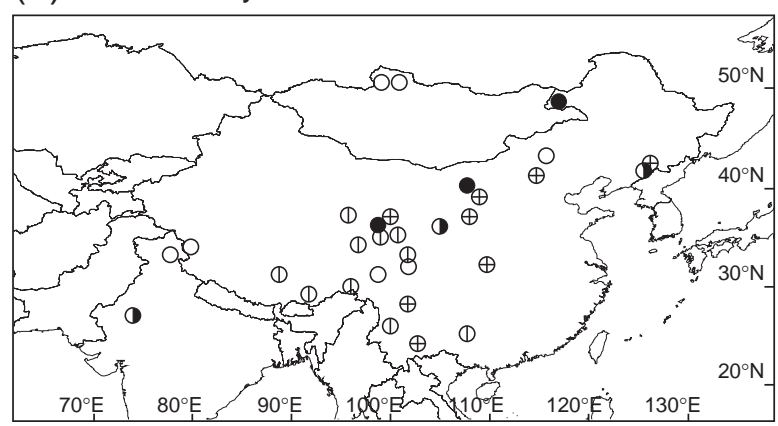

(d) early Holocene (10-7 cal. kyr BP)

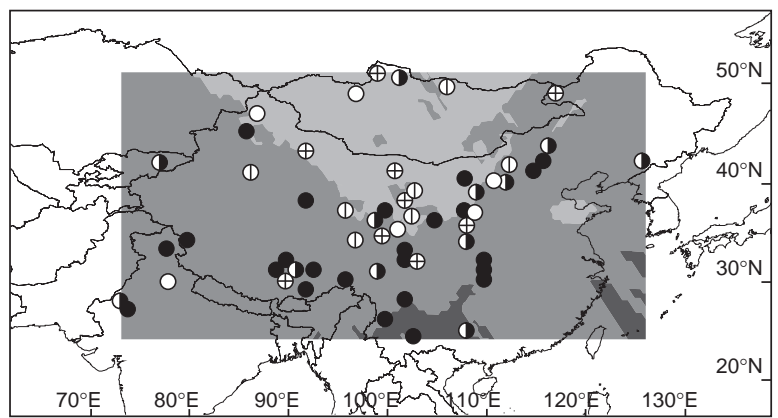

(f) late Holocene (4 cal. kyr BP - Present)

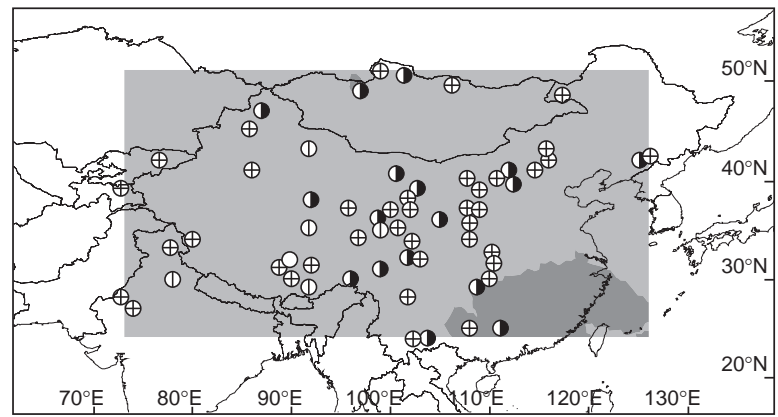

(h)Younger Dryas

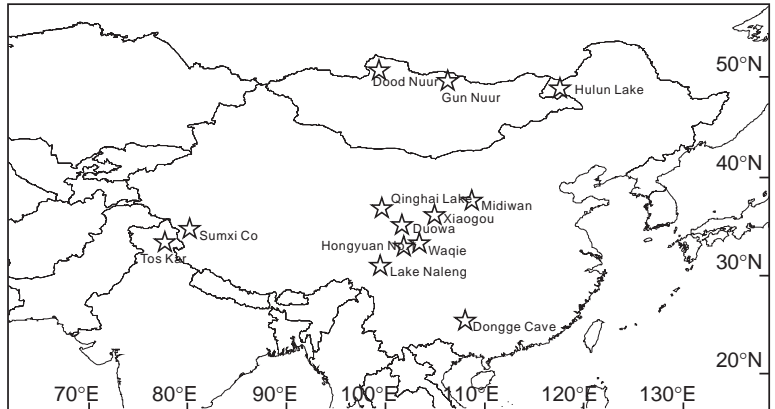

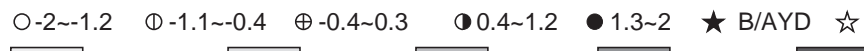

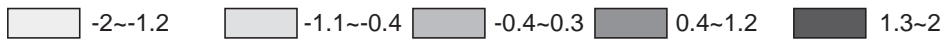

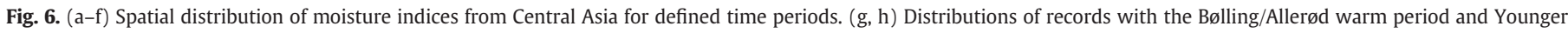

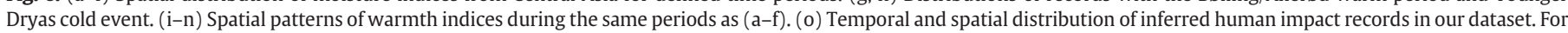
moisture and warmth indices, symbols indicate the values for each site during certain periods while the gray bands present the interpolated zones through Kriging model. 
(i) $18-15$ cal. kyr BP

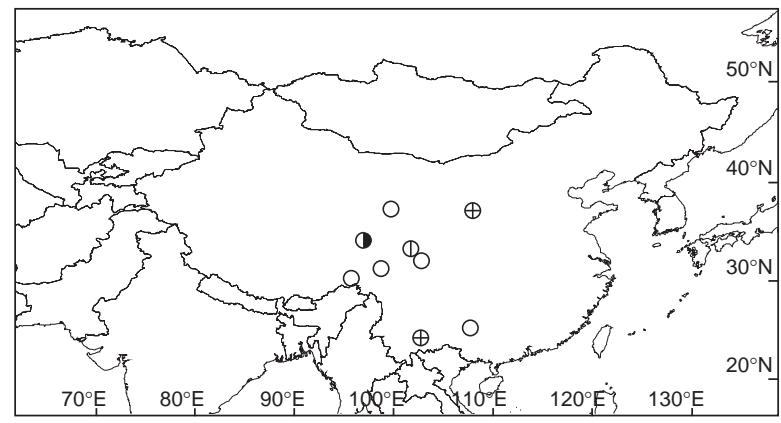

(k) Holocene Transition (12-10 cal. kyr BP)

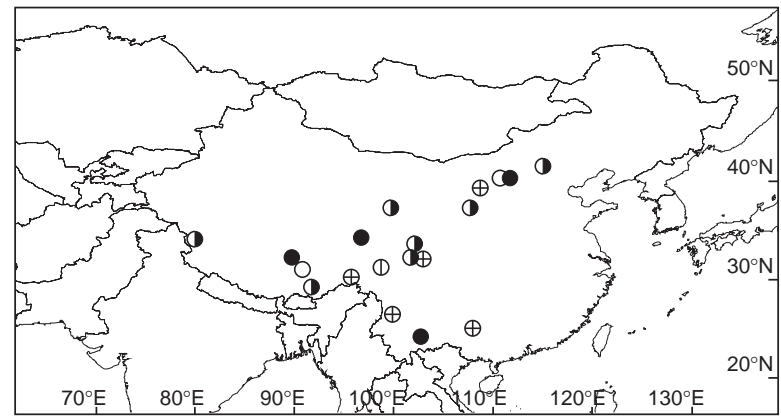

(m)mid Holocene (7-4 cal. kyr BP)

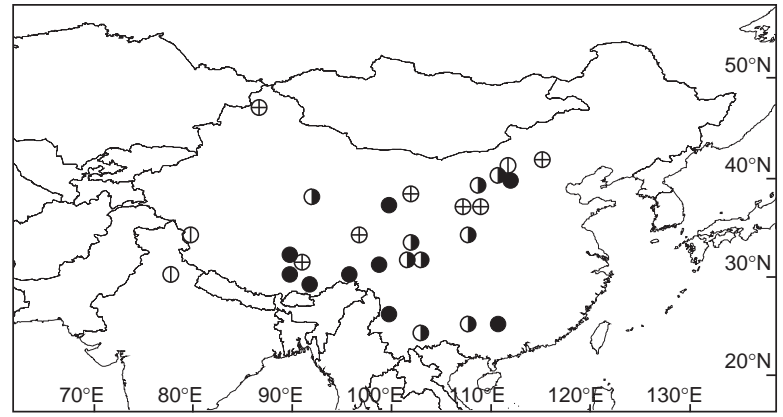

(0)Inferred human impacts

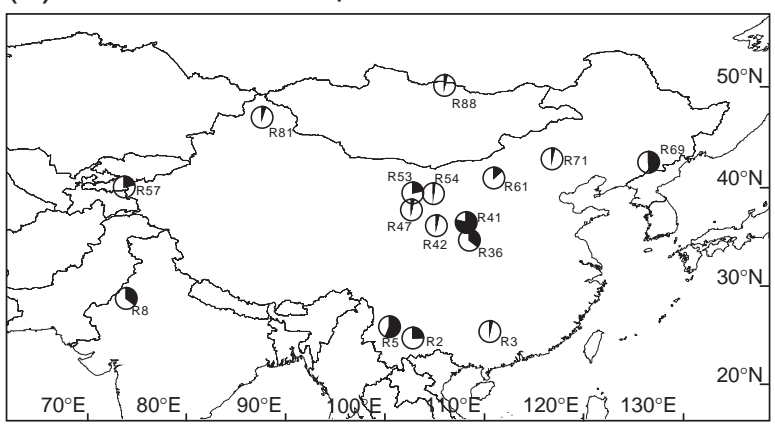

(j) 15-12 cal. kyr BP

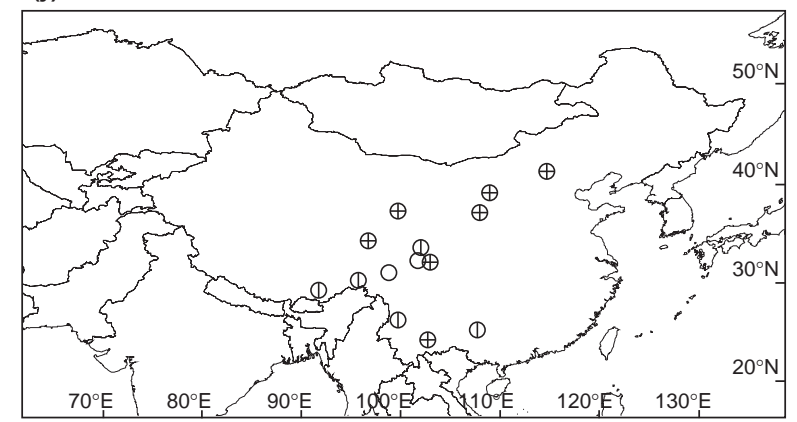

(I) early Holocene (10-7 cal. kyr BP)

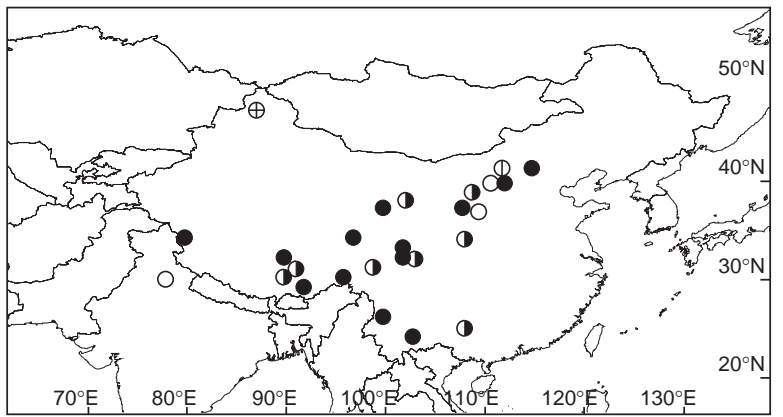

(n) late Holocene (4 cal. kyr BP - Present)

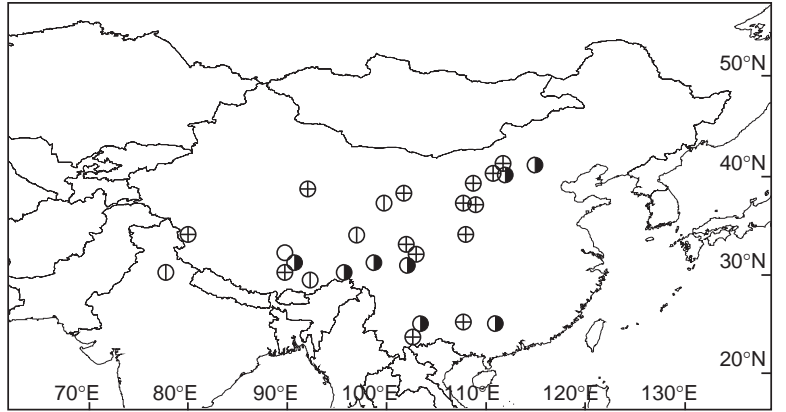

O-2 -1.2 $\oplus-1.1 \sim-0.4 \oplus-0.4 \sim 0.3 \quad 0.4 \sim 1.2 \quad \bullet 1.3 \sim 2$

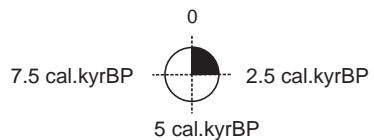

Fig. 6 (continued).

the summer monsoon after the LGM which is also documented in marine and stalagmite records from across the Asian monsoonal regions (Hodell et al., 1999; Dykoski et al., 2005; Shen et al., 2006; Fleitmann et al., 2007).

When considering average moisture and warmth indices across the whole study area, the early Holocene (10-7 cal. kyr BP, Figs. 3 and 6d, j) represents the wettest and warmest phase since $18 \mathrm{cal}$. kyr BP. This period is also recognized as the Holocene Optimum period in reviews by An et al. (2000) and Herzschuh (2006), and is furthermore consistent with a maximum in the Asian Summer Monsoon recorded in ice core records from Tibetan Plateau (Guliya, Thompson et al., 1997; Dunde, Liu et al., 1998), marine records (Overpeck et al., 1996) and terrestrial monsoon records from outside our study area (Fleitmann et al., 2003, 2007). The mapping of moisture indices reveals regional differences. 
Whilst maximum moisture conditions are concentrated in southwest China, records from Mongolia, Inner Mongolia and Xinjiang indicate moderately dry conditions consistent with a period of low lake levels observed by Chen et al. (2008). However, newly published climatic data from two Mongolian lakes, Hoton Nur (Rudaya et al., 2009) and Lake Hovsgol (Murakami et al., 2009), imply that the early Holocene was characterised by a moisture optimum which is probably indicative of strong spatial differences in the moisture history of Mongolia during the early Holocene.

The period between 7 and 4 cal. kyr BP (Fig. 6e, m) is still warm and wet on average but is characterized by a clear southeastnorthwest moisture gradient which is different from the early Holocene wet phase. Maximum moisture levels in southeast China were attained during the mid-Holocene which is explained by the 'southward moving Holocene Optimum Period' hypothesis outlined by An et al. (2000) despite the potential uncertainty raised from their low resolution records. However maximum moisture levels during the mid-Holocene were also recorded in Korea (Fujiki and Yasuda, 2004; Nahm et al., 2006), Japan (Schöne et al., 2004) and the East China Sea area (Li et al., 1997). In contrast, decreasing moisture levels were recorded in northern India, southwest China and in other terrestrial archives from the Indian Summer Monsoonal area such as the stalagmite records (Fleitmann et al., 2003; Dykoski et al., 2005; Fleitmann et al., 2007; etc.) and marine records from Arabian Sea (Overpeck et al., 1996; Gupta et al., 2003), which are unanimously related to decreasing monsoonal activity.

For the last 4000 years, the environment has been more or less equal to the present day, apart from a number of weak moisture signals from southeast China. The overall conditions are slightly drier than those during the previous stage that was assigned to a further decrease in the Asian Summer Monsoon (Liu et al., 2001; Huang et al., 2004; Dykoski et al., 2005; Shao et al., 2006; Cosford et al., 2008; Hu et al., 2008).

In summary, climatic changes in monsoonal central Asia area follow a global pattern, with significant coherence with high-latitude ice core records and low-latitude marine sequences. However, our meta-analyses revealed marked spatial patterns in Asian moisture history that are not yet fully understood in terms of the driving mechanisms.

\subsection{The asynchronous nature of the Asian monsoonal subsystems: past and present}

The PCA analysis performed on the entire region reveals potential moisture evolution patterns. PC1 retains relative high values from 10 to 7 cal. kyr BP, followed by a gradual decrease towards present-day levels, exhibiting high values in northern India, Tibet and southwest China (Figs. 4a, 5). Similar patterns have also been reported from other areas influenced by the Indian Summer Monsoon such as the Arabian Sea (Overpeck et al., 1996; Gupta et al., 2003) and southern Oman (Fleitmann et al., 2003, 2007). This pattern, coherent with the PC1 values from the individual sub-regions (Figs. 2a; $4 \mathrm{c}$ ), indicates the expanded influence of Asian Summer Monsoon during the early Holocene, accounting for the synchronous increases in moisture levels at the beginning of Holocene and the following moisture maximum, which is well recorded in each sub-region (see supplementary, Fig. S1).

However, apart from this overall trend, regional differences in moisture evolution which originate from additional moisture sources or from moisture-suppressing mechanisms are indicated by the PC2 axis results from each sub-region (Fig. 4d). PCA axis 2 of the ISM region exhibits an additional strong moisture signal during the early Holocene (8-7 cal. kyr BP), but starts to decrease after 7 cal. kyr BP. This is probably indicative of the retreat of the ISM (Fig. S1). The PC2 scores from the EASM region account for as much as $21 \%$ of the total variance and reveal that many records, especially cave records from central eastern China (Liu et al., 2001; Shao et al., 2006; Cosford et al., 2008; Hu et al., 2008), were subject to a maximum moisture supply during the mid Holocene (7-4.5 cal. kyr BP) (Figs. 4d, S1). A similar pattern is seen in by records from the Korean peninsula (Fujiki and Yasuda, 2004; Nahm et al., 2006) and in marine records from the East China Sea (Li et al., 1997) and the Japan Sea (Jian et al., 2000; Schöne et al., 2004). Thus, after spatial-temporal analyses, the two primary signals revealed in PCA analysis over the whole region can be interpreted as indices of the Asian Summer Monsoon subsystems with PC1 indicating the Indian Summer Monsoon and PC2 the East Asian Summer Monsoon.

The PC2 scores from the region outside of the present monsoon boundary (Fig. 4d) indicates that many records show a wet stage between 5 and 2 cal. kyr BP (Fig. S1). Considering the transitional position of this region and the regression of Asian Summer Monsoon, these wet conditions during the late-Holocene probably reflect the influence of the Westerlies as was reported by Vandenberghe et al. (2006) and Chen et al. (2008). However, probably owing to the lack of continuous records, our study does not confirm an out-of-phase moisture evolution pattern during the mid and late Holocene in the arid central Asian area as reported by Chen et al. (2008) who described a dry early Holocene (12-8 cal. kyr BP) and relatively wet mid to late Holocene (since ca. 7 cal. kyr BP).

Hence, the regions influenced by the two Asian Summer Monsoon sub-systems evolved in notably different ways during the first half of the Holocene. The Indian Summer Monsoon (PC1) mirrored the path of Northern Hemisphere solar insolation, presenting a decreasing trend throughout the Holocene with maximum rates of change during the mid-Holocene. In contrast, the East Asian Summer Monsoon (PC2) shows a maximum moisture period between 7 and 4 cal. kyr BP which occurred immediately after the intense Indian Summer Monsoon period ended. Reassessing the main driving forces and mechanisms of Asian Summer Monsoon, namely insolation (1), sea surface temperature (2) and Hadley Circulation (3), may be the key to understand the different patterns of the two subsystems.

(1) The strength of the Indian Summer Monsoon is assumed to be largely driven by the summer ocean-continent temperature gradient that depends on insolation changes on the Tibetan Plateau at $\sim 30^{\circ} \mathrm{N}$ (Ruddiman and Kutzbach, 1989; Sirocko et al., 1993; Overpeck et al., 1996; Y.J. Wang et al., 2001; Fleitmann et al., 2003; Yuan et al., 2004; P.X. Wang et al., 2005; Y.J. Wang et al., 2005; Fleitmann et al., 2007). The land-ocean contrast of the East Asian Summer Monsoon area reflects insolation changes in the low-elevation Asian interior between 30 and $50^{\circ} \mathrm{N}$. As the pattern of the insolation curves are approximately similar between 30 and $50^{\circ} \mathrm{N}$, the asynchronous nature of the monsoonal subsystems is not forced by regional insolation differences on the Asian continent.

(2) Moreover, palaeo-SST records from marine areas surrounding southern and eastern Asia (MD77194, Arabian Sea, Sonzogni et al., 1998; 74KL, Arabian Sea, Sonzogni et al., 1998; GC18287-3, South China Sea, Steinke et al., 2001; Core 17940-1/2, South China Sea, Wang et al., 1999; Core-255, East China Sea, Li et al., 1997; Core-B3GC, middle Okinawa Trough, Jian et al., 2000; MD76, western tropical Pacific Ocean, Stott et al., 2004), show similar, relatively stable conditions during the Holocene, negating a potential Oceanic Thermal driven hypothesis.

(3) Hadley circulation, which is defined as global zonal-symmetric meridional circulation (Oort and Yienger, 1996), has been widely recognized as an important factor for the evolution of the Asian Summer Monsoon (Joseph, 1978; Tanaka et al., 2004; Mitas and Clement, 2006).

Based on meteorological data from the NCEP/NCAR reanalysis database, we reconstructed the Indian Summer Monsoonal Hadley $\left(\mathrm{MH}_{\mathrm{ISM}}\right)$ Index for the ISM region $\left(70^{\circ} \mathrm{E}-110^{\circ} \mathrm{E}, 10^{\circ} \mathrm{N}-30^{\circ} \mathrm{N}\right)$ since 
(a)

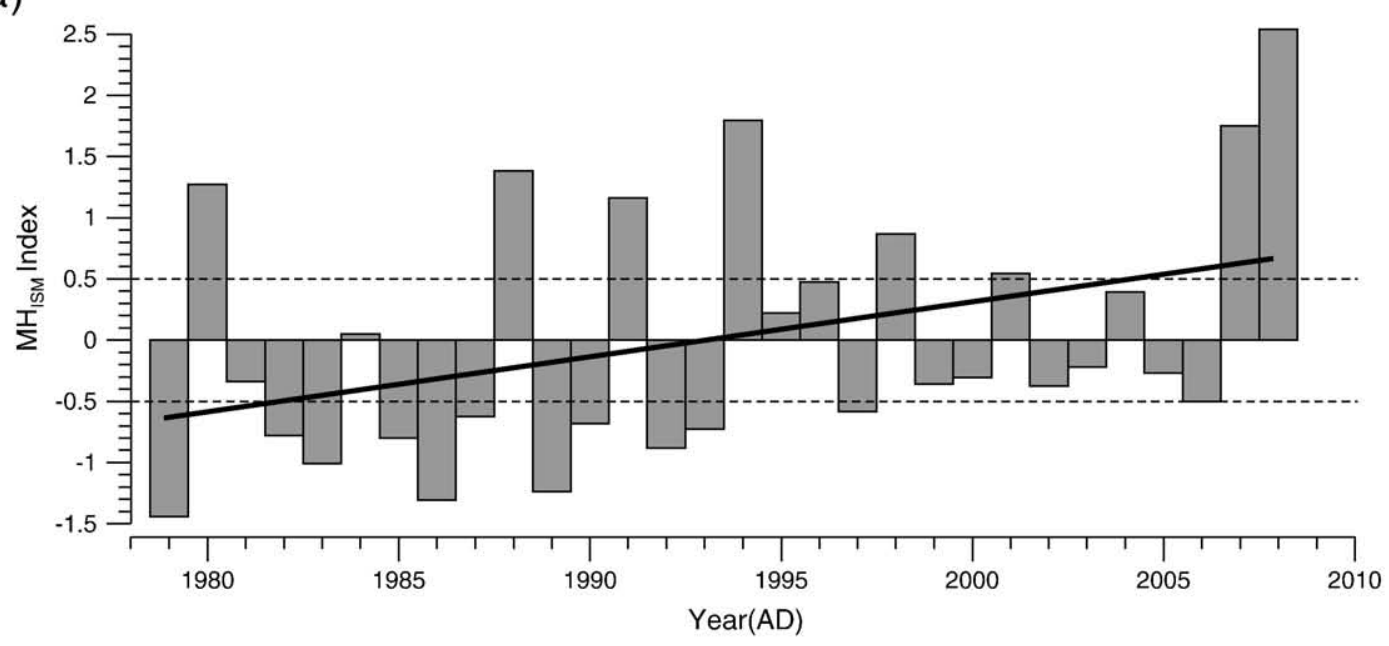

(b)

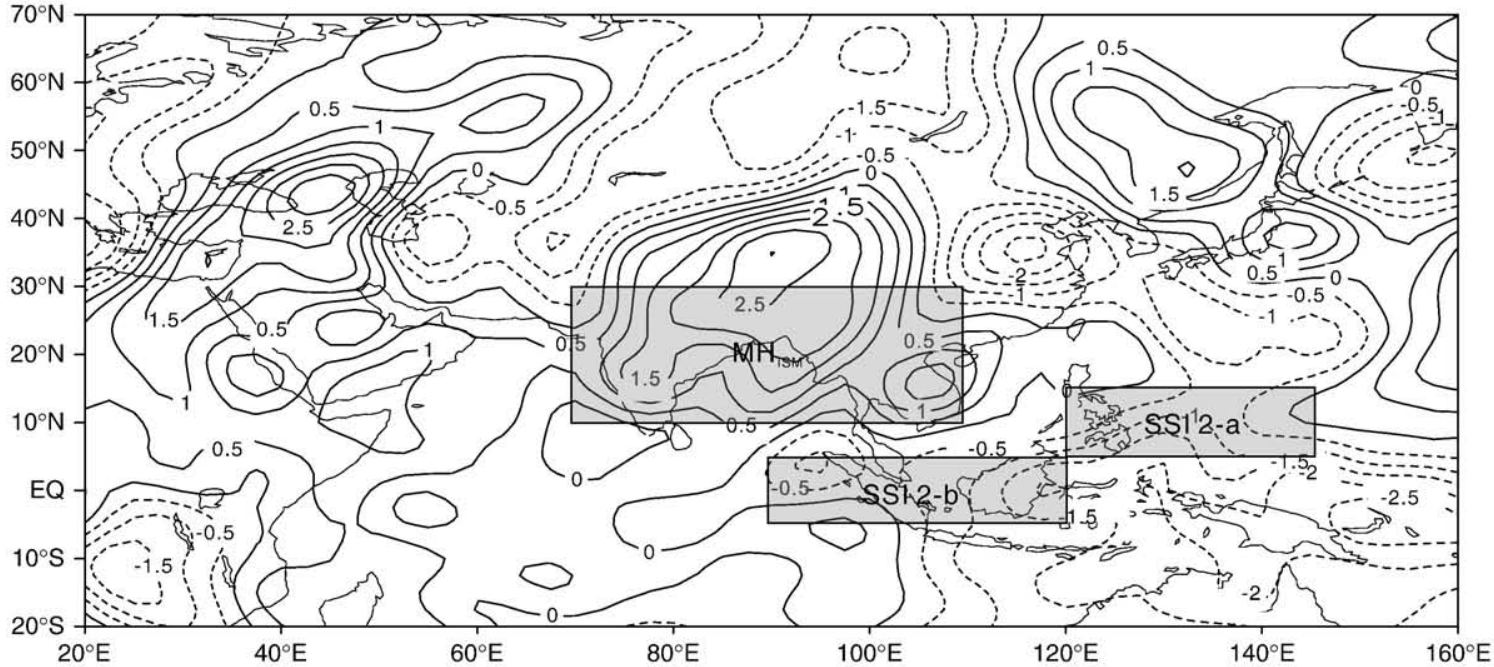

(c)

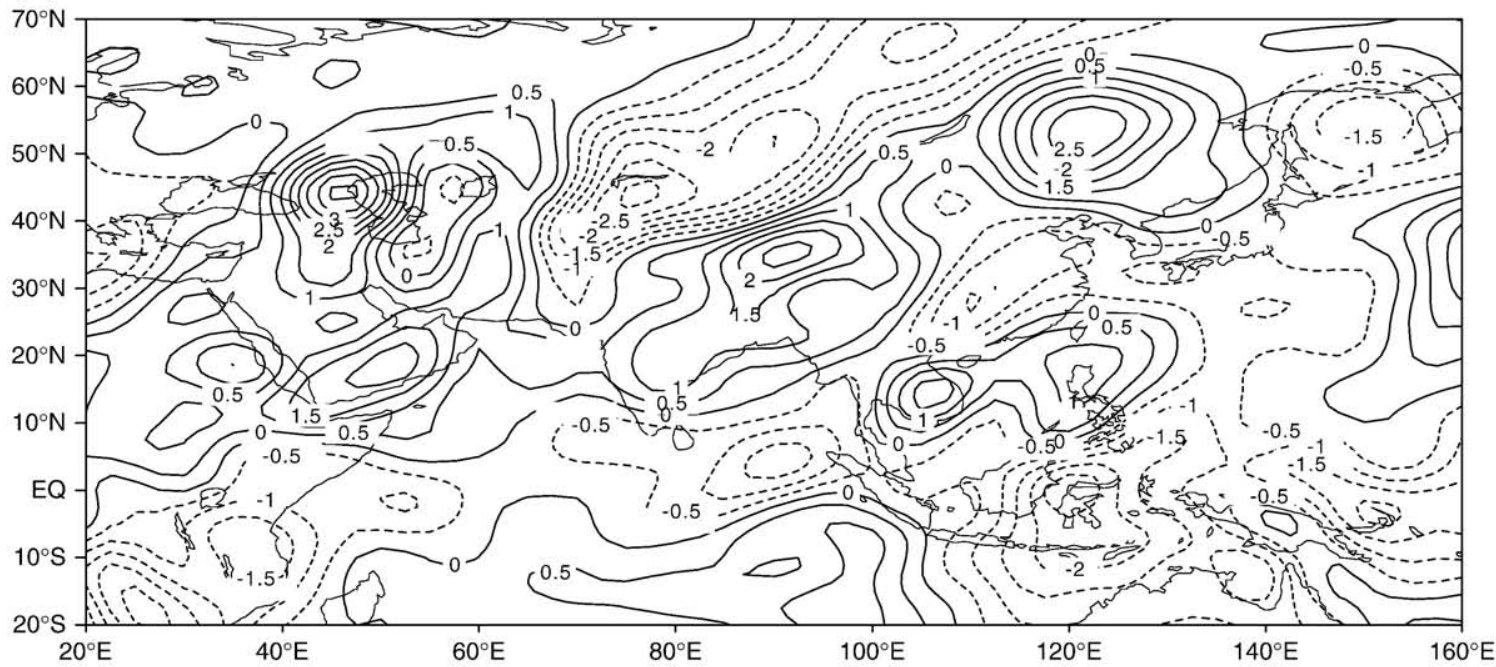

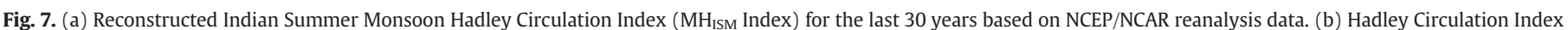

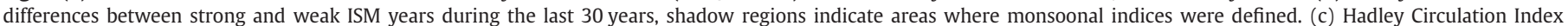

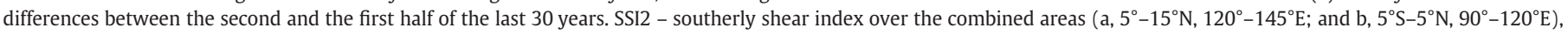
defined in Wang and Fan (1999). 


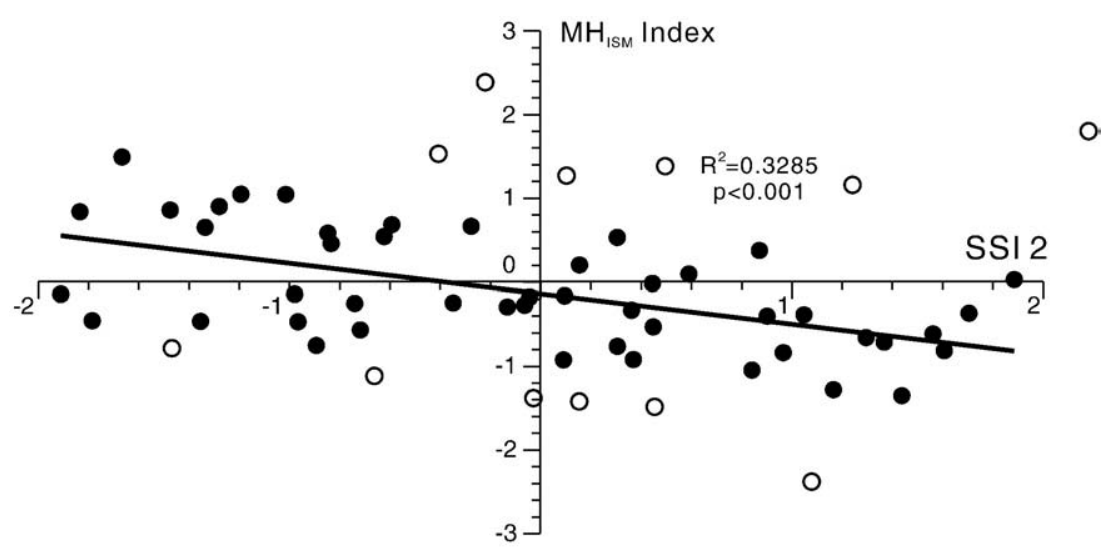

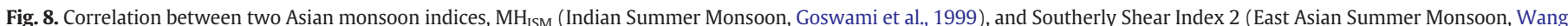

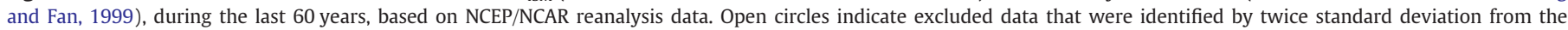
regression line. Most of the years excluded show extreme El Niňo/La Niňa events (e.g. 1988, 1991 and 1994).

1979 (Fig. 7a), following the method described by Goswami et al. (1999), which was proven to be consistent with monsoonal precipitation indices (Indian Monsoon Rainfall and Extended Indian Monsoon Rainfall). Calculated as the anomalous meridional windshear, the broader scale Monsoonal Hadley $(\mathrm{MH})$ Index is also suitable for describing the whole Asian Summer Monsoon system based on meteorological data from an extended area $\left(20^{\circ} \mathrm{E}-160^{\circ} \mathrm{E}, 20^{\circ} \mathrm{S}-70^{\circ} \mathrm{N}\right)$ (Goswami et al., 1999). The difference in the MH index between strong ISM years (with $\mathrm{MH}_{\text {ISM }}$ index above +0.5 ) and weak ISM years (with $\mathrm{MH}_{\mathrm{ISM}}$ index below -0.5) is shown in Fig. 7b. Compared to the weak ISM years, relatively high values during strong ISM years were found in northern India, southwest China and some southern Asia areas, confirming the strong influences of the ISM system. Interestingly, areas surrounding this positive centre all showed negative values, indicating a weaker wind-shear that most probably hinders ascendance of even cause descending airflow in comparison with normal years. In particular, the north-central China region situated in the EASM region shows strong negative values. Considering a further dynamic index for EASM defined as Southerly Shear Index (SSI2) by Wang and Fan (1999), a generally negative correlation between modern ISM and EASM $\left(R^{2}=0.3285, p<0.001\right)$ is achieved for the last 60 years (Fig. 8). The low $R$-value may be caused by further teleconnections which add variation to the monsoon systems such as the Southern Oscillation (SO) and El Niňo that are supposed to influence the Asian Summer Monsoon (Shukla and Paolino, 1983; Meehl and Arblaster, 1998), as well as Arctic Oscillation (AO), Northern Atlantic Oscillation (NAO) and Siberia High (SH) from the Northern Hemisphere (Wu and Wang, 2002a,b) that strongly influence the Asian Winter Monsoon.

Furthermore, we assume that a strong Hadley Circulation formed over Bengal Bay, northern India and southwest China, during the early Holocene (10-7 cal. kyr BP) following an increase in Northern Hemisphere solar insolation, resulting in intense Indian Summer Monsoon (see above). Subsequently, strong ascending currents over the heated Tibetan Plateau led to relatively weaker ascending (or even descending) airflows over north-central China area, which can confirmed by the modern vertical wind patterns (Fig. 9). Fig. 9 (a-c) show vertical wind velocity differences between years with strong and weak Tibetan ascending airflows, for three sections: a, $30^{\circ} \mathrm{N}$; b, $90^{\circ} \mathrm{E} ; \mathrm{c}, 115^{\circ} \mathrm{E}$. Stronger ascending trends are indicated by negative values (dash lines), while relatively weaker ascending (or descending) airflows were expressed as positive values (solid lines). Obviously, when stronger ascending airflows happened over Tibetan Plateau area, relatively weaker ascending or even descending currents dominated the north-central China area $\left(20^{\circ} \mathrm{N}-50^{\circ} \mathrm{N}, 110^{\circ} \mathrm{E}-150^{\circ} \mathrm{E}\right)$. By analogy to the modern data, restrained rising air currents in the north-central China region prevented a strengthening of the EASM, resulting a relatively dry phase during the early Holocene. During the mid-Holocene (7-4 cal. kyr BP), the ISM began to retreat due to a decrease in solar insolation, that resulted in a weakening of the suppressing effects over EASM areas allowing an enhancement of the EASM leading to a moisture maximum not only in north-central China (Liu et al., 2001; Shao et al., 2006; Cosford et al., 2008; Hu et al., 2008), but also in Korea, Japan and the East China Sea area (Li et al., 1997; Fujiki and Yasuda, 2004; Schöne et al., 2004; Nahm et al., 2006). Since this time, under the influence of a further decrease in Northern Hemisphere insolation, both ASM subsystems developed towards modern conditions.

In summary, during the Holocene, the evolution of the Asian Summer Monsoon was primarily controlled by Northern Hemisphere solar insolation changes in conjunction with internal interactions between the two subsystems.

\section{Conclusions}

Our synthesis of 92 palaeoclimatic proxy records (72 sites) indicates that the moisture and temperature history in monsoonal central Asia during the last 18,000 years has generally followed the patterns of the northern hemisphere described in other records. The synthesis curve indicates that monsoon strengthening since the LGM occurred in a rather stepwise fashion whilst the monsoonal retreat since the mid-Holocene has been gradual. The approximately synchronous environmental signals revealed by pollen and nonpollen records negated the potential of human-driven ecosystems except for the last 1000 years where we found significant biases. Our results also indicate that feedbacks between climate change and the human impact on ecosystems were of minor importance during most of the Holocene.

Despite the similar overall trend, we found significant regional differences in the moisture evolution patterns of the last 10,000 years. The ordination analyses revealed different moisture evolution patterns among EASM, ISM areas and the region outside of present monsoon boundary. The increasing moisture levels at many sites outside the present monsoon boundary during the late Holocene are possibly related to the influence of the Westerlies. Furthermore, whilst moisture evolution in the ISM area roughly follows Northern Hemisphere summer insolation reaching a maximum during the early Holocene, many sites in the EASM area stays relatively dry and reaches its maximum moisture levels between 7 and 4 cal. kyr BP. We assume that enhanced Hadley Circulation leads to stronger upperlevel air transport into the EASM monsoon region which regionally hinders ascending airflow motion and hence suppresses monsoonal 
(a)

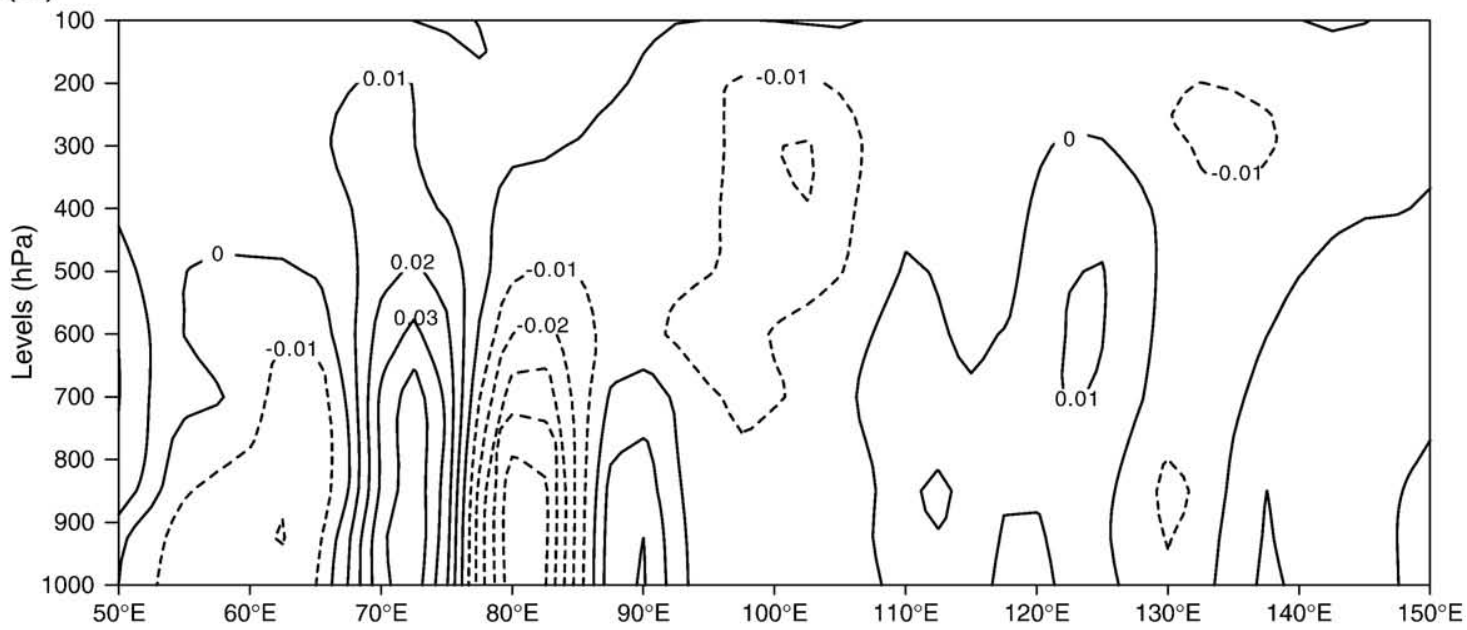

(b)

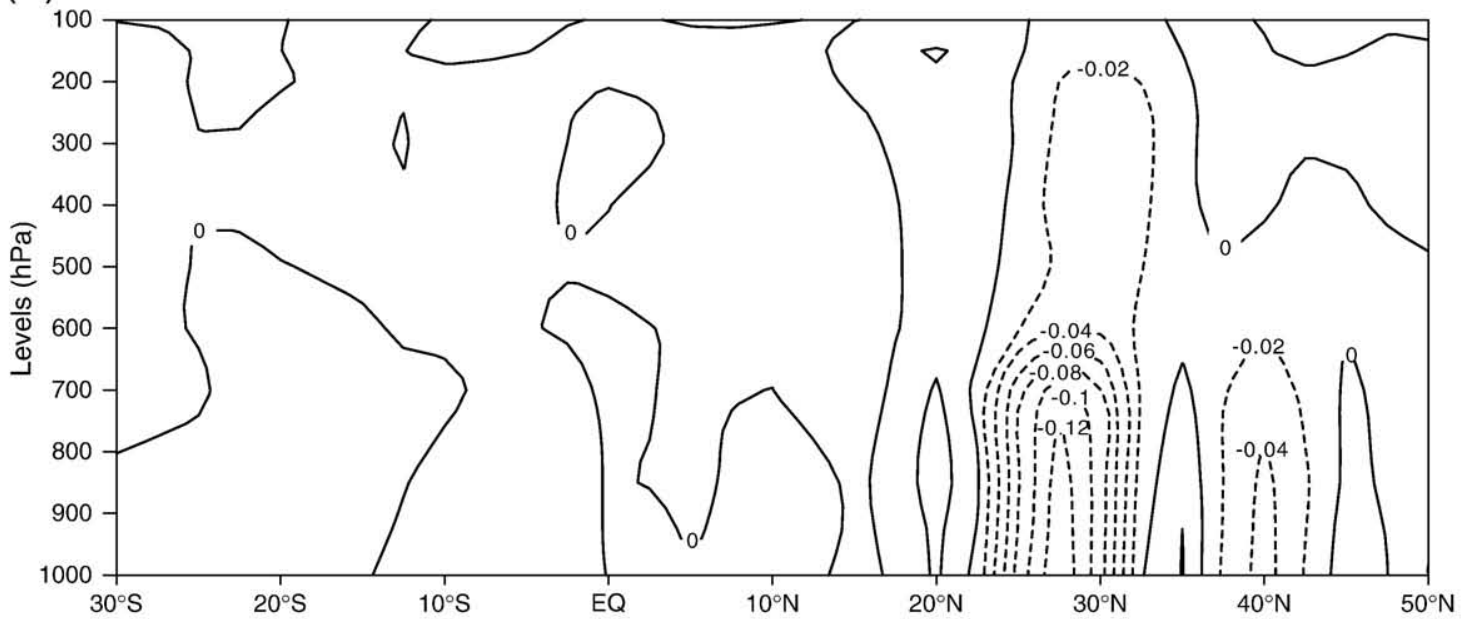

(c)

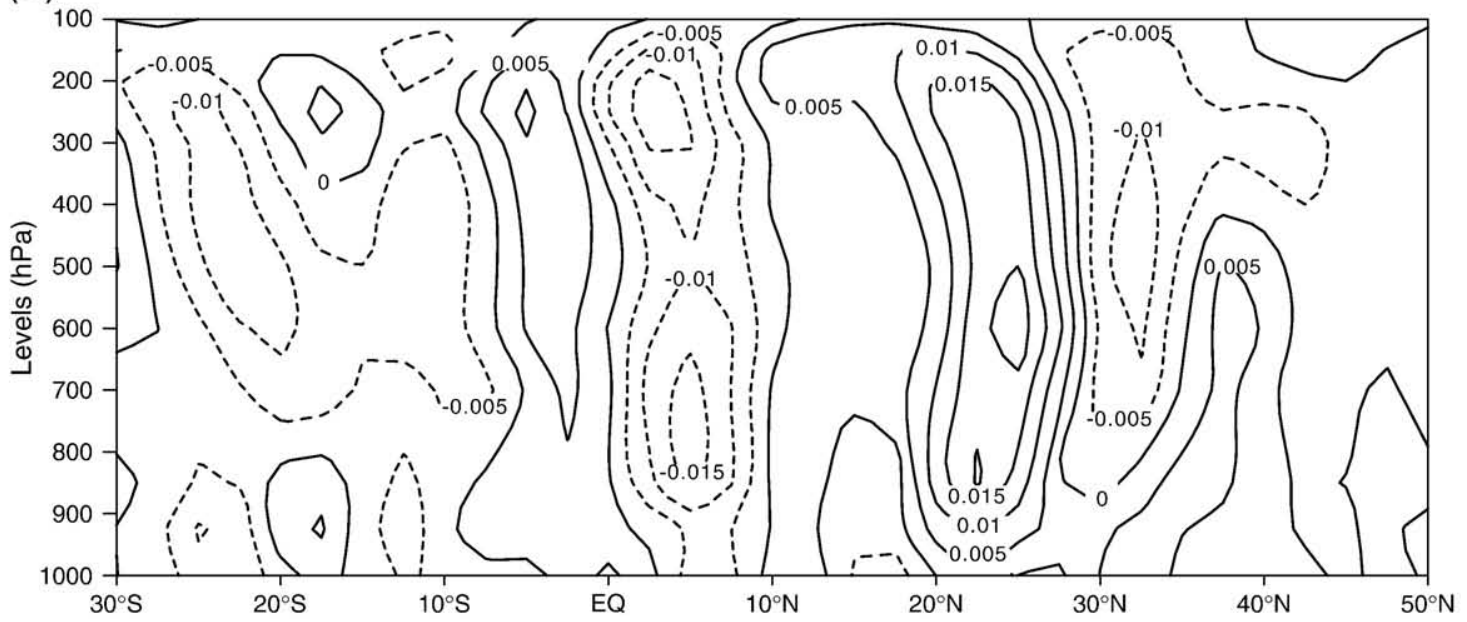

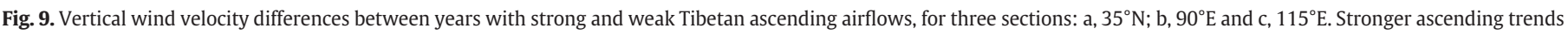
were indicated by negative values (dash lines), while relatively weaker ascending (or descending) airflows were expressed as positive values (solid lines).

circulation. Interpretation of a dynamic Monsoonal Hadley index $\left(\mathrm{MH}_{\mathrm{ISM}}\right)$ that was calculated for the last 30 years using NCEP/NCAR data reveals the same pattern when comparing weak to strong ISM years confirming our mechanistic explanation of the asynchronous nature of the Asian monsoonal subsystems.
Moreover, the reconstructed $\mathrm{MH}_{\mathrm{ISM}}$ Index (Fig. 7a) increased during the last 30 years confirming observations of an increasing ISM in recent years (Fleitmann et al., 2003; Gupta et al., 2003; Yuan et al., 2004; Dykoski et al., 2005; Y.J. Wang et al., 2005; Fleitmann et al., 2007). Consequently, when comparing the MH Index of 1979-1994 to 
last 15 years (1995-2008) a similar pattern was observed as when comparing weak to strong ISM years (Fig. 7c). This implies that the stronger the ISM becomes in the future, the more the upward air motion in the EASM region will be suppressed which is probably related to drier conditions observed there. This implies that the arid desert-steppe areas of north-central China, being the dust source areas for e.g. Beijing dust storm events (Qian et al., 2002; Zhang et al., 2003; X. Wang et al., 2008a; Y.B. Wang et al., 2008) might suffer from increasing dryness in the future. An early Holocene dust maximum observed in the Sihailongwan Maar Lake sediment record (Schettler et al., 2006), about $900 \mathrm{~km}$ east of Beijing, may be able to analogise to the future time in case that anthropogenically-driven strengthening of Hadley Circulation in Asia will persist. However, the further decreasing summer insolation will probably moderate this effect.

\section{Acknowledgements}

Special thanks to Hongli Wang (niglas) for her assistance in the analyses of modern meteorological data. We are grateful to Juliane Wischnewski (AWI-Potsdam) for her help in numerical analyses. Y. Wang's doctoral research is funded by "Helmholtz - China Scholarship Council (CSC) Young Scientist Fellowship” (No. 2008491101). The research was supported by German Science Foundation (DFG), the National Natural Science Foundation of China (Grant No. 40772108) and Nanjing Institute of Geography and Limnology, CAS (No. NIGLAS2010XK01). We appreciate the helpful comments of two anonymous reviewers.

\section{Appendix A. Supplementary data}

Supplementary data to this article can be found online at doi:10.1016/j.earscirev.2010.09.004.

\section{References}

An, Z.S., Porter, S.C., Kutzbach, J.E., Wu, X.H., Wang, S.M., Liu, X.D., Li, X.Q., Zhou, W.J., 2000. Asynchronous Holocene optimum of the East Asian monsoon. Quaternary Science Reviews 19, 743-762.

Beer, R., Heiri, O., Tinner, W., 2007. Vegetation history, fire history and lake development recorded for 6300 years by pollen, charcoal, loss on ignition and chironomids at a small lake in southern Kyrgyzstan (Alay Range, Central Asia). The Holocene 17 (7), 977-985.

Berman, F., Chien, A., Cooper, K., Dongarra, J., Foster, L., Gannon, D., Johnsson, L., Kennedy, K., Kesselman, C., Mellor-Crumme, J., Reed, D., Torczon, L., Wolski, R., 2001. The GrADS Project: Software Support for High-Level Grid Application Development. International Journal of High Performance Computing Applications $15,327-344$.

Bush, A.B.G., 2001. Pacific Sea Surface Temperature forcing dominates orbital forcing of the early Holocene monsoon. Quaternary Research 55 (1), 25-32.

Bush, A.B.G., 2005. $\mathrm{CO}_{2} / \mathrm{H}_{2} \mathrm{O}$ and orbitally driven climate variability over central Asia through the Holocene. Quaternary International 136 (1), 15-23.

Campo, E.V., Cour, P., Hang, S.X., 1996. Holocene environmental changes in Bangong Co basin (Western Tibet). Part 2: The pollen record. Palaeogeography, Palaeoclimatology, Palaeoecology 120, 49-63.

Chang, C.P., Harr, P., Ju, J.H., 2000. Possible roles of Atlantic circulation on the weakening Indian Monsoon Rainfall-ENSO relationship. Journal of Climate 14, 2376-2380.

Chen, F.H., Wu, W., Holmes, J.A., Madsen, D.B., Zhu, Y., Jin, M., Oviatt, C.G., 2003. A midHolocene drought interval as evidenced by lake desiccation in the Alashan Plateau, Inner Mongolia, China. Chinese Science Bulletin 48 (14), 1401-1410.

Chen, F.H., Cheng, B., Zhao, Y., Zhu, Y., Madsen, D.B., 2006. Holocene environmental change inferred from a high-resolution pollen record, Lake Zhuyeze, arid China. The Holocene 16, 675-684

Chen, F.H., Yu, Z.C., Yang, M.L., Ito, E., Wang, S.M., Madsen, D.B., Huang, X.Z., Zhao, Y., Sato, T., John, H., Birks, B., Boomer, I., Chen, J.H., An, C.B., Wünnemann, B., 2008. Holocene moisture evolution in arid central Asia and its out-of-phase relationship with Asian monsoon history. Quaternary Science Reviews 27, 351-364.

Clift, P.D., Plumb, R.A., 2008. The Asian Monsoon: causes, history and effects. Cambridge University Press

Cosford, J., Qing, H.R., Eglington, B., Mattey, D., Yuan, D.X., Zhang, M.L., Cheng, H., 2008. East Asian monsoon variability since the mid-Holocene recorded in a high resolution absolute-dated aragonite speleothem from eastern China. Earth and Planetary Science Letters 275, 296-307.

Cowling, S.A., Sykes, M.T., 1999. Physiological significance of low atmosphere $\mathrm{CO}_{2}$ for plant -climate interactions. Quaternary Research 52, 237-242.
Dansgaard, W., White, J.W.C., Johnsen, S.J., 1989. The abrupt termination of the Younger Dryas climate event. Nature 339, 532-534.

Dearing, J.A., Jones, R.T., Shen, J., Yang, X., Boyle, J.F., Foster, G.C., Crook, D.S., Elvin, M.J.D., 2008. Using multiple archives to understand past and present climate-humanenvironment interactions: the lake Erhai catchment, Yunnan Province, China. Journal of Paleolimnology 40, 3-31.

Demske, D., Tarasov, P.E., Wünnemann, B., Riedel, F., 2009. Late glacial and Holocene vegetation, Indian monsoon and westerly circulation in the Trans-Himalaya recorded in the lacustrine pollen sequence from Tso Kar, Ladakh, NW India. Palaeogeography, Palaeoclimatology, Palaeoecology 279, 172-185.

Dorofeyuk, N.I., Tarasov, P.E., 1998. Vegetation and lake levels in northern Mongolia in the last 12,500 years as indicated by data of pollen and diatom analyses. Stratigraphy and Geological Correlations 6 (1), 70-83.

Dykoski, C.A., Edwards, R.L., Cheng, H., Yuan, D.X., Cai, Y.J., Zhang, M.L., Lin, Y.S., Qing, J.M., An, Z.S., Revenaugh, J., 2005. A high-resolution, absolute-dated Holocene and deglacial Asian monsoon record from Dongge Cave, China. Earth and Planetary Science Letters 233, 71-86.

Enzel, Y., Ely, L.L., Mishra, S., Ramesh, R., Amit, R., Lazar, B., Rajagure, S.N., Baker, V.R., Sandler, A., 1999. High-resolution Holocene environmental changes in the Thar Desert, northwestern India. Science 284, 125-128.

Feng, Z.D., Wang, W.G., Guo, L.L., Khosbayar, P., Narantsetseg, T., Jull, A.J.T., An, C.B., Li, X.Q., Ma, Y.Z., 2005. Lacustrine and eolian records of Holocene climate changes in the Mongolian Plateau: preliminary results. Quaternary International 136, 25-32.

Fleitmann, D., Burns, S.J., Mudelsee, M., Neff, U., Kramers, J., Mangini, A., Matter, A., 2003. Holocene forcing of the Indian Monsoon recorded in a stalagmite from southern Oman. Science 300, 1737-1939.

Fleitmann, D., Burns, S.J., Mangini, A., Mudelsee, M., Kramers, J., Villa, I., Neff, U., AlSubbary, A.A., Buettner, A., Hippler, D., Matter, A., 2007. Holocene ITCZ and Indian monsoon dynamics recorded in stalagmites from Oman and Yemen (Socotra). Quaternary Science Reviews 26, 170-188.

Fontes, J.C., Gasse, F., Gibert, E., 1996. Holocene environmental changes in Lake Bangong basin (Western Tibet). Part 1: Chronology and stable isotopes of carbonates of a Holocene lacustrine core. Palaeogeography, Palaeoclimatology, Palaeoecology 120, 25-47.

Fowell, S.J., Hansen, B.C.S., Peck, J.A., Khosbayar, P., Ganbold, E., 2003. Mid to late Holocene climate evolution of the Lake Telmen Basin, north central Mongolia, based on palynological data. Quaternary Research 59, 353-363.

Fujiki, T., Yasuda, Y., 2004. Vegetation history during the Holocene from Lake Hyangho. Quaternary International. 123-125, 63-69.

Gasse, F., Arnold, M., Fontes, J.C., Fort, M., Gibert, E., Huc, A., Li, B.Y., Li, Y.F., Liu, Q., Melieres, M., Campo, E.V., Wang, F.B., Zhang, Q.S., 1991. A 13000-year climate record from western Tibet. Nature 353, 742-745.

Goswami, B.N., Krishnamurthy, V., Annamalai, H., 1999. A broad-scale circulation index for the interannual variability of the Indian summer monsoon. The Quaternary Journal of Royal Meteorological Society 125, 611-633.

Grootes, P.M., Stuiver, M., White, J.W.C., Johnsen, S., Jouzel, J., 1993. Comparison of oxygen isotope records from the GISP2 and GRIP Greenland ice cores. Nature 366, 552-554.

Gupta, A.K., Anderson, D.M., Overpeck, J.T., 2003. Abrupt changes in the Asian southwest monsoon during the Holocene and their links to the North Atlantic Ocean. Nature 421, 354-357.

He, Y., Theakstone, W.H., Zhang, Z.L., Zhang, D., Yao, T.D., Chen, T., Shen, Y.P., Pan, H.X. 2004. Asynchronous Holocene climate change across China. Quaternary Research 61, 52-63.

Herzschuh, U., 2006. Palaeo-moisture evolution in monsoonal Central Asia during the last 50,000 years. Quaternary Science Reviews 25, 163-178.

Herzschuh, U., Tarasov, P., Wünnemann, B., Hartmann, K., 2004. Holocene vegetation and climate of the Alashan Plateau, NW China, reconstructed from pollen data. Palaeogeography, Palaeoclimatology, Palaeoecology 211, 1-17.

Herzschuh, U., Winter, K., Wünnemann, B., Li, S.J., 2006. A general cooling trend on the central Tibetan Plateau throughout the Holocene recorded by the Lake Zigetang pollen spectra. Quaternary International 154-155, 113-121.

Herzschuh, U., Kramer, A., Mischke, S., Zhang, C.J., 2009. Quantitative climate and vegetation trends since the late glacial on the northeastern Tibetan Plateau deduced from Koucha lake pollen spectra. Quaternary Research 71 (2), $162-171$.

Hodell, D.A., Brenner, M., Kanfoush, S.L., Curtis, J.H., Stoner, J.S., Song, X.L., Wu, Y., 1999 Paleoclimate of southwestern China for the past 50,000 yr inferred from lake sediment records. Quaternary Research 52, 369-380.

Hong, Y.T., Hong, B., Lin, Q.H., Shibata, Y., Hirota, M., Zhu, Y.X., Leng, X.T., Wang, Y., Wang, H., Yi, L., 2005. Inverse phase oscillations between the East Asian and Indian Ocean summer monsoons during the last 12000 years and paleo-El Nino. Earth and Planetary Science Letters 231, 337-346.

Hu, C.Y., Henderson, G.M., Huang, J.H., Xie, S.C., Sun, Y., Johnson, K.R., 2008 Quantification of Holocene Asian monsoon rainfall from spatially separated cave records. Earth and Planetary Science Letters 266, 221-232.

Huang, G., 2004. An index measuring the interannual variability of the East Asian Summer Monsoon - the EAP Index. Advances in Atmospheric Sciences 20 (1), 41-52.

Huang, C.C., Pang, J.L., Zhou, Q.Y., Chen, S.E., 2004. Holocene pedogenic changes and the emergence and decline of rain-fed cereal agriculture on the Chinese Loess Plateau. Quaternary Science Reviews 23, 2525-2535.

Huang, X.Z., Chen, F.H., Fan, Y.X., Yang, M.L., 2009. Dry late-glacial and early Holocene climate in arid central Asia indicated by lithological and palynological evidence from Bosten Lake, China. Quaternary International 194, 19-27.

Hughen, K.A., Southon, J.R., Lehman, S.J., Overpeck, J.T., 2000. Synchronous radiocarbon and climate shifts during the last Deglaciation. Science 290, 1951-1954. 
Jackson, S.T., Williams, J.W., 2004. Modern analogs in Quaternary paleoecology: Here today, gone yesterday, gone tomorrow? Annual Review of Earth and Planetary Sciences 32, 495-537.

Jarvis, D.I., 1993. Pollen evidence of changing Holocene monsoon climate in Sichuan province, China. Quaternary Research 39, 325-337.

Ji, J.F., Shen, J., Balsam, W., Chen, J., Liu, L.W., Liu, X.Q., 2005. Asian monsoon oscillations in the northeastern Qinghai-Tibet Plateau since the late glacial as interpreted from visible reflectance of Qinghai Lake sediments. Earth and Planetary Science Letters $233,61-70$

Ji, J.F., Balsam, W., Shen, J., Wang, M., Wang, H.T., Chen, J., 2009. Centennial blooming of anoxygenic phototrophic bacteria in Qinghai Lake linked to solar and monsoon activities during the last 18,000 years. Quaternary Science Reviews 28 (13-14), 1304-1308.

Jian, Z.M., Wang, P.X., Saito, Y., Wang, J.L., Pflaumann, U., Oba, T., Cheng, X.R., 2000. Holocene variability of Kuroshio Current in the Okinawa Trough, northwestern Pacific Ocean. Earth and Planetary Science Letters 184, 305-319.

Jiang, W.Y., Guo, Z.T., Sun, X.J., Wu, H.B., Chu, G.Q., Yuan, B.Y., Hatte, C., Guiot, J., 2006 Reconstruction of climate and vegetation changes of Lake Bayanchagan (Inner Mongolia): Holocene variability of the East Asian monsoon. Quaternary Research 65, 411-420.

Johnston, K., Verhoef, J.M., Krivoruchko, K., Lucas, N., 2001. Using ArcGISTM Geostatistical Analyst. Redlands, California. 49 pp.

Joseph, P.V., 1978. Subtropical westerlies in relation to large scale failure of Indian summer monsoon. Indian Journal of Meteorology, Hydrology and Geophysics 29 412-418.

Kalnay, E., Kanamitsu, M., Kistler, R., Collins, W., Deaven, D., Gandin, L., Iredell, M., Saha S., White, G., Wollen, J., Zhu, Y., Leetmaa, A., Reynolds, R., Chelliah, M., Ebisuzaki, W. Higgins, W., Janowiak, J., Mo, K.C., Ropelewskim, C., Wang, J., 1996. The NCEP/NCAR 40-year reanalysis project. Bulletin of the American Meteorological Society 77 437-471.

Kistler, R., Kalnay, E., Collins, W., Saha, S., White, G., Woollen, J., Chelliah, M., Ebisuzaki, W., Kanamitsu, M., Kousky, V., van den Dool, H., Jenne, R., Fiorino, M., 2001. The NCEP/ NCAR 50-year reanalysis. Bulletin of the American Meteorological Society $82,247-267$

Kramer, A., Herzschuh, U., Mischke, S., Zhang, C.J., 2009a. Late glacial vegetation and climate oscillations on the southeastern Tibetan Plateau inferred from Lake Naleng pollen profile. Quaternary Research 73 (2), 324-335.

Kramer, A., Herzschuh, U., Mischke, S., Zhang, C.J., 2009b. Holocene treeline shifts and monsoon variability in the Hengduan Mountains (southeastern Tibet Plateau) implications from palynological investigations. Palaeogeography, Palaeoclimatology, Palaeoecology 286 (1-2), 23-41.

Laskar, L., Robute, P., Joute, F., Gastineau, M., Correia, A.C.M., Levrard, B., 2004. A longterm numerical solution for the insolation quantities of the Earth. Astronomy \& Astrophysics 428, 261-285.

Li, B.H., Jian, Z.M., Wang, P.X., 1997. Pulleniatina obliquiloculata as a paleoceanographic indicator in the southern Okinawa Trough during the last 20, 000 years. Marine Micropaleontology 32, 59-69.

Li, X.Q., Zhou, W.J., An, Z.S., Dodson, J., 2003. The vegetation and monsoon variations at the desert-loess transition belt at Midiwan in northern China for the last $13 \mathrm{ka}$. The Holocene 13 (5), 779-784.

Linsley, B.K., 1996. Oxygen-isotope record of sea level and climate variations in the Sulu Sea over the past 150,000 years. Nature $380,234-237$

Lister, G.S., Kelts, K., Chen, K.Z., Yu, J.Q., Niessen, F., 1991. Lake Qinghai, China: closed-basin lake levels and the oxygen isotope record for ostracoda since the latest Pleistocene. Palaeogeography, Palaeoclimatology, Palaeoecology 84 $141-162$

Liu, K.B., Yao, Z.J., Thompson, L.G. 1998. A pollen record of Holocene climatic changes from the Dunde ice cap, Qinghai-Tibetan Plateau. Geology 26 (2), 135-138.

Liu, H.P., Tang, X.C., Sun, D.H., Wang, K.F., 2001. Palynofloras of the Dajiuhu Basin in Shennongjia Mountains during the last $12.5 \mathrm{ka}$. Acta Mircropalaeontologica Sinica 18 (1), 101-109 (in Chinese with English Abstract).

Liu, H.Y., Xu, L.H., Cai, H.T., 2002a. Holocene history of desertification along the woodland-steppe border in northern China. Quaternary Research 57, 259-270.

Liu, X.O., Shen, J., Wang, S.M., Yang, X.D., Tong, G.B., Zhang, E.L., 2002b. A 16000-year pollen record of Qinghai Lake and its paleoclimate and paleoenvironment. Chinese Science Bulletin 47 (22), 1931-1936.

Liu, X.Q., Shen, J., Wang, S.M., Wang, Y.B., Liu, W.G., 2007. Southwest monsoon changes indicated by oxygen isotope of ostracode shells from sediments in Qinghai Lake since the late Glacial. Chinese Science Bulletin 52 (4), 539-544.

Liu, X.Q., Dong, H.L., Rech, J.A., Matsumoto, R., Yang, B., Wang, Y.B., 2008a. Evolution of Chaka Salt Lake in NW China in response to climatic change during the latest Pleistocene-Holocene. Quaternary Science Reviews 27, 867-879.

Liu, X.Q., Herzschuh, U., Shen, J., Jiang, Q.F., Xiao, X.Y., 2008b. Holocene environmental and climatic changes inferred from Wulungu Lake in northern Xinjiang, China. Quaternary Research 70, 412-425.

Ma, Y.Z., Zhang, H.C., Pachur, H.J., Wünnemann, B., Li, J.J., Feng, Z.D., 2004. Modern pollen-based interpretations of mid-Holocene palaeoclimate (8500 to $3000 \mathrm{cal}$. BP at the southern margin of the Tengger Desert, northwestern China. The Holocene 14 (6), 841-850.

Maher, B.A., 2008. Holocene variability of the East Asian summer monsoon from Chinese cave records: a re-assessment. The Holocene 18, 861-866.

Maher, B.A., Hu, M.Y., 2006. A high-resolution record of Holocene rainfall variations from the western Chinese Loess Plateau: antiphase behaviour of the African/Indian and East Asian summer monsoons. The Holocene 16, 309-320.

Mardia, K.V., Kent, J.T., Bibby, J.M., 1979. Multivariate Analysis. Academic Press, London. 521 pp.
Meehl, G.A., Arblaster, J.M., 1998. The Asian-Australian Monsoon and El Niňo-Southern Oscillation in the NCAR Climate System Model. Journal of Climate 11, 1356-1385.

Mischke, S., Wünennmann, B., 2006. The Holocene salinity history of Bosten Lake (Xinjiang, China) inferred from ostracod species assemblages and shell chemistry: Possible palaeoclimatic implications. Quaternary International 154-155, 100-112.

Mischke, S., Demske, D., Wünennmann, B., Schudack, M.E., 2005. Groundwater discharge to a Gobi desert lake during Mid and Late Holocene dry periods. Palaeogeography, Palaeoclimatology, Palaeoecology 225, 157-172.

Mischke, S., Kramer, M., Zhang, C.J., Shang, H.M., Herzschuh, U., Erzinger, J., 2008. Reduced early Holocene moisture availability in the Bayan Har Mountains, northeastern Tibetan Plateau, inferred from a multi-proxy lake record. Palaeogeography, Palaeoclimatology, Palaeoecology 267, 59-76.

Mitas, C.M., Clement, A., 2006. Recent behavior of the Hadley cell and tropical thermo -dynamics in climate models and reanalyses. Geophysical Research Letters 33, L01810. doi:10.1029/2005GL024406.

Morinaga, H., Itota, C., Isezaki, N., Goto, H., Yaskawa, K., Kusakabe, M., 1993. Oxygen-18 and carbon-13 records for the last 14,000 years from lacustrine carbonates of Siling-Co (Lake) in the Qinghai-Tibetan Plateau. Geophysical Research Letters 20 (24), 2909-2912.

Morrill, C., Overpeck, J.T., Cole, J.E., 2003. A synthesis of abrupt changes in the Asian summer monsoon since the last deglaciation. The Holocene 13, 465-467.

Morrill, C., Overpeck, J.T., Cole, J.E., Liu, K.B., Shen, C.M., Tang, L.Y., 2006. Holocene variations in the Asian monsoon inferred from the geochemistry of lake sediments in central Tibet. Quaternary Research 65, 232-243.

Murakami, T., Katsuta, N., Yamamoto, K., Takamatsu, N., Takano, M., Oda, T., Matsumoto, G.I., Horiuchi, K., Kawai, T., 2009. A 27-kyr record of environmental change in central Asia inferred from the sediment record of Lake Hovsgol, northwest Mongolia. Journal of Paleolimnology. doi:10.1007/s10933-009-9336-5.

Nahm, W.H., Kim, J.K., Yang, D.Y., Kim, J.Y., Yi, S., Yu, K.M., 2006. Holocene paleosols of the Upo wetland, Korea: their implications for wetland formation. Quaternary International 144, 53-60.

Oort, A.H., Yienger, J.J., 1996. Observed interannual variability in the Hadley circulation and its connection to ENSO. Journal of Climate 9, 2751-2767.

Oppo, D.W., Linsley, B.K., Rosenthal, Y., Dannenmann, S., Beaufort, L., 2003. Orbital and suborbital climate variability in the Sulu Sea, western tropical Pacific. Geochemistry, Geophysics, Geosystems 4 (1), 1003-1022.

Overpeck, J., Anderson, D., Trumbore, S., Prell, W., 1996. The southwest Indian Monsoon over the last 18000 years. Climate Dynamics 12, 213-225.

Peck, J.A., Khosbayar, P., Fowell, S.J., Pearce, R.B., Ariunbileg, S., Hansen, B.C.S., Soninkhishig, N., 2002. Mid to late Holocene climate change in north central Mongolia as recorded in the sediments of Lake Telmen. Palaeogeography, Palaeoclimatology, Palaeoecology 183, 135-153.

Peres-Neto, P.R., Jackson, D.A., 2001. How well do multivariate data sets match? The advantages of a Procrustean superimposition approach over the Mantel test. Oecologia 129, 169-178.

Petit, J.R., Jouzel, J., Raynaud, D., Barkov, N.I., Barnola, J.-M., Basile, I., Bender, M., Chappellaz, J., Davis, M., Delaygue, G., Delmotte, M., Kotlyakov, V.M., Legrand, M., Lipenkov, V.Y., Lorius, C., Pepin, L., Ritz, C., Saltzman, E., Stievenard, M., 1999. Climate and atmospheric history of the past 420,000 years from the Vostok ice core, Antarctica. Nature 399, 429-436.

Phadtare, N.R., 2000. Sharp decrease in summer monsoon strength 4000-3500 cal. yr B.P. in the central higher Himalaya of India based on pollen evidence from Alpine peat. Quaternary Research 53, 122-129.

Porter, S.C., An, Z.S., 1995. Correlation between climate events in the north Atlantic and China during the last Glaciation. Nature 375, 305-308.

Qian, W.H., Quan, L.S., Shi, S.Y., 2002. Variations of dust storm in China and its climatic control. Journal of Climate 15, 1216-1229.

Reimer, P.J., Baillie, M.G.L., Bard, E., Bayliss, A., Beck, J.W., Bertrand, C.J.H., Blackwell, P.G., Buck, C.E., Burr, G.S., Cutler, K.B., Damon, P.E., Edwards, R.L., Fairbanks, R.G., Friedrich, M., Guilderson, T.P., Hogg, A.G., Hughen, K.A., Kromer, B., McCormac, F.G., Manning, S.W., Ramsey, C.B., Reimer, R.W., Remmele, S., Southon, J.R., Stuiver, M., Talamo, S., Taylor, F.W., van der Plicht, J., Weyhenmeyer, C.E., 2004. IntCal04, Terrestrial radiocarbon age calibration, 26-0 ka BP. Radiocarbon 46, 1029-1058.

Rhodes, T.E., Gasse, F., Lin, R.F., Fontes, J.C., Wei, K.Q., Bertrand, P., Gibert, E., Melieres, F. Tucholka, P., Wang, Z.X., Chen, Z.Y., 1996. A Late Pleistocene-Holocene lacustrine record from Lake Manas, Zunggar (northern Xinjiang, western China). Palaeogeography, Palaeoclimatology, Palaeoecology 120, 105-121.

Ricketts, R.D., Johnson, T.C., Brown, E.T. Rasmussen, K.A., Romanovsky, V.V., 2001. The Holocene paleolimnology of Lake Issyk-Kul, Kyrgyzstan: trace element and stable isotope composition of ostracodes. Palaeogeography, Palaeoclimatology, Palaeoecology $176,207-227$.

Rudaya, N., Tarasov, P., Dorofeyuk, N., Solovieva, N., Kalugin, I., Andreev, A., Darvin, A., Diekmann, B., Riedel, F., Tserendash, N., Wagner, M., 2009. Holocene environments and climate in the Mongolian Altai reconstructed from the Hoton-Nur pollen and diatom records: a step towards better understanding climate dynamics in Central Asia. Quaternary Science Reviews 28, 540-554.

Ruddiman, W.F., Kutzbach, J.E., 1989. Forcing of the Cenozoic northern hemisphere climate by plateau uplift in southern Asia and the American west. Journal of Geophysical Research 94 (15), 18409-18427.

Sato, T., 2009. Influences of subtropical jet and Tibetan Plateau on precipitation pattern in Asia: insights from regional climate modeling. Quaternary International 194, $148-158$

Schettler, G., Liu, Q., Mingram, J., Stebich, M., Dulski, P., 2006. East-Asian monsoon variability between 15,000 and 2000 cal. yr BP recorded in varved sediments of Lake Sihailongwan (northeastern China, Long Gang volcanic field). The Holocene 16, 1043-1057. 
Schöne, B.R., Oschmann, W., Tanabe, K., Dettman, D., Fiebig, J., Houk, S.D., Kanie, Y., 2004 Holocene seasonal environmental trends at Tokyo Bay, Japan, reconstructed from bivalve mollusk shells - implications for changes in the East Asian monsoon and latitudinal shifts of the Polar Front. Quaternary Science Reviews 23, 1137-1150.

Seppa, H., Bennett, K.D., 2003. Quaternary pollen analysis: recent progress in palaeoecology and palaeolimatology. Progress in Physical Geography 27 (4), $548-579$.

Shao, X.H., Wang, Y.J., Cheng, H., Kong, X.G., Wu, J.Y., Lawrence, E.R., 2006. Long-term trend and abrupt events of the Holocene Asian monsoon inferred from a stalagmite $\delta^{18} \mathrm{O}$ record from Shennongjia in Central China. Chinese Science Bulletin 51 (2), 221-228.

Shen, J., Liu, X.Q., Wang, S.M., Matsumoto, R., 2005. Palaeoclimatic changes in the Qinghai Lake area during the last 18,000 years. Quaternary International 136, 131-140.

Shen, J., Jones, R.T., Yang, X.D., Dearing, J.A., Wang, S.M., 2006. The Holocene vegetation history of Lake Erhai, Yunnan province southwestern China: the role of climate and human forcings. The Holocene 16, 265-277.

Shen, C.M., Liu, K.B., Morrill, C., Overpeck, J.T., Peng, J.L., Tang, L.Y., 2008. Ecotone shift and major droughts during the min-late Holocene in the central Tibetan Plateau. Ecology 89 (4), 1079-1088.

Shi, P.J., Song, C.Q., 2003. Palynological records of environmental changes in the middle part of Inner Mongolia, China. Chinese Science Bulletin 48 (14), 1433-1438.

Shukla, J., Paolino, D.A., 1983. The Southern Oscillation and long range forecasting of the Summer Monsoon Rainfall over India. Monthly Weather Review 11, 1830-1837.

Singh, G., Wasson, R.J., Agrawal, D.P., 1990. Vegetational and seasonal climatic changes since the last full glacial in the Thar Desert, northwestern India. Review of Palaeobotany and Palynology 64, 351-358.

Sirocko, F., Sarnthein, M., Erlenkeuser, H., Lange, H., Arnold, M., Duplessy, J.C., 1993. Century-scale events in monsoonal climate over the past 24,000 years. Nature 364 , 322-324.

Sonzogni, C., Bard, E., Rostek, F., 1998. Tropical Sea-Surface Temperatures during the last Glacial period: a view based on alkenones in Indian Ocean sediments. Quaternary Science Reviews 17, 1185-1201.

Sowers, T., Bender, M., Labeyrie, L., Martinson, D., Jouzel, J., Rynaud, D., Korotkevich, Y.S. 1993. A 135,000-year Vostok-SPECMAP common temporal framework. Paleoceanography 8 (6), 737-766.

Steinke, S., Kienast, M., Pflaumann, U., Weinelt, M., Stattegger, K., 2001. A highresolution Sea-Surface Temperature record from the tropical South China Sea (16,500-3000 yr B.P.). Quaternary Research 55, 352-362.

Stott, L., Cannariato, K., Thunell, R., Haug, G.H., Koutavas, A., Lund, S., 2004. Decline of surface temperature and salinity in the western tropical Pacific Ocean in the Holocene epoch. Nature 431, 56-59.

Stuiver, M., Grootes, P.M., Braziunas, T.F., 1995. The GISP2 $\delta 180$ climate record of the past 16,500 years and the role of the Sun, Ocean and Volcanoes. Quaternary Research 44 (3), 341-354.

Tanaka, H.L., Ishizaki, N., Kitoh, A., 2004. Trend and interannual variability of Walker, monsoon and Hadley circulations defined by velocity potential in the upper troposphere. Tellus 56A, 250-269.

Tang, L.Y., Shen, C.M., Liu, K.B., Overpeck, J.T., 2000. Changes in south Asian monsoon: new high-resolution paleoclimatic records from Tibet, China. Chinese Science Bulletin 45 (1), 87-90.

ter Braak, C.J.F., Smilauer, P., 2002. Canoco for windows 4.5. Biometrics, the Netherlands. 550 pp.

Thompson, L.G., Mosley-Thompson, E., Davis, M.E., Bolzan, J.F., Dai, J., Klein, L., Gundestrup, N., Yao, T.D., Wu, X., Xie, Z., 1990. Glacial stage ice-core records from the subtropical Dunde Ice Cap, China. Annuals of Glaciology 14, 288-297.

Thompson, L.G., Yao, T.D., Davis, M.E., Henderson, K.A., Mosley-Thompson, E., Lin, P.N., Beer, J., Synal, H.A., Cole-Dai, J., Bolzan, J.F., 1997. Tropical climate instability: the last Glacial cycle from a Qinghai-Tibetan Ice Core. Science 276, 1821-1825.

Vandenberghe, J., Renssen, H., Huissteden, K., Nugteren, G., Konert, M., Lu, H.Y., Dodonov, A., Buylaert, J.-P., 2006. Penetration of Atlantic westerly winds into Central and East Asia. Quaternary Science Reviews 25, 2380-2389.

Wang, B., 2006. The Asian Monsoon. Springer, Chichester. 685 pp.

Wang, B., Fan, Z., 1999. Choice of south Asian Summer Monsoon indices. Bulletin of American Meteorological Society 80 (4), 629-638.

Wang, Y., Song, C.Q., Sun, X.J., 1997. Palynological record of paleovegetation change during Holocene at north Tumote Plain in Inner Mongolia, China. Acta Geographica Sinica 52 (5), 430-438 (in Chinese with English Abstract).

Wang, L.J., Sarnthein, M., Erlenkeuser, H., Grootes, P.M., Grimalt, J.O., Pelejero, C., Linck, G., 1999. Holocene variations in Asian Monsoon moisture: a bidecadal sediment record from the South China Sea. Geophysical Research letters 26 (18), 2889-2892.

Wang, B., Wu, R.G., Lau, K.M., 2001a. Interannual variability of the Asian Summer Monsoon: contrasts between the Indian and Western North Pacific-East Asian Monsoon. Journal of Climate 14 (29), 4073-4090.

Wang, H.Y., Liu, H.Y., Cui, H.T., Abrahamsen, N., 2001b. Terminal Pleistocene/Holocene palaeo-environmental changes revealed by mineral-magnetism measurements of lake sediments for Dali Nor area, southeastern Inner Mongolia Plateau, China. Palaeogeography, Palaeo -climatology, Palaeoecology 170, 115-132.

Wang, Y.J., Cheng, H., Edwards, R.L., An, Z.S., Wu, J.Y., Shen, C.C., Dorale, J.A., 2001c. A high resolution absolute-dated late Pleistocene monsoon record from Hulu Cave, China. Science 294, 2345-2348.

Wang, H., Hong, Y.T., Zhu, Y.X., Hong, B., Lin, Q.H., Xu, H., Leng, X.T., Mao, X.M., 2004. Humification degrees of peat in Qinghai-Xizang Plateau and palaeoclimate change. Chinese Science Bulletin 49 (5), 514-519.

Wang, P.X., Clemens, S., Beaufort, L., Braconnot, P., Ganssen, G., Jian, Z.M., Kershaw, P., Sarnthein, M., 2005a. Evolution and variability of the Asian monsoon system: state of the art and outstanding issues. Quaternary Science Reviews 24 (5-6), 595-629.
Wang, Y.J., Cheng, H., Edwards, R.L., He, Y.Q., Kong, X.G., An, Z.S., Wu, J.Y., Kelly, M.J. Dykoski, C.A., Li, X.D., 2005b. The Holocene Asian Monsoon links to Solar changes and North Atlantic Climate. Science 308, 854-857.

Wang, X., Huang, J.P., Ji, M.X., Higuchi, K., 2008a. Variability of East Asia dust events and their long-term trend. Atmospheric Environment 42, 3156-3165.

Wang, Y.B., Liu, X.Q., Yang, X.D., Zhang, E.L., Matsumoto, R., 2008b. A 4000-year moisture evolution recorded by sediments of Lake Kusai in the Hoh Xil area, northern Tibetan Plateau. Journal of Lake Sciences 20 (5), 605-612 (in Chinese with English Abstract).

Weaver, A.J., Saenko, O.A., Clark, P.U., Mitrovica, J.X., 2003. Melt water pulse 1A from Antarctica as a trigger of the Bølling-Allerød warm interval. Science 299, 1709-1713.

Webster, P.J., Yang, S., 1992. Monsoon and ENSO: selectively interactive systems. The Quaternary Journal of Royal Meteorological Society 118 (507), 877-926.

Webster, P.J., Magana, V.O., Palmer, T.N., Shukla, J., Tomas, R.A., Yanai, M., Yasunari, T. 1998. Monsoons: processes, predictability, and the prospects for prediction. Journal of Geophysical Research 103, 14451-14510.

Wischnewski, J., Herzschuh, U., Mischke, S., Wang, Y.B., 2010. Reconstructing post-late glacial climate variability on the northeastern Tibetan Plateau - a multi - proxy, dual - site approach comparing terrestrial and aquatic signals. Quaternary Science Reviews. doi:10.1016/j.quascirev.2010.10.001.

Wu, B.Y., Wang, J., 2002a. Winter Arctic Oscillation, Siberia High and East Asian Winter Monsoon. Geophysical Research Letters 29, 1897-1990.

Wu, B.Y., Wang, J., 2002b. Possible impacts of winter Arctic Oscillation on Siberian high, the East Asian winter monsoon and sea-ice extent. Advances in Atmospheric Sciences 19, 297-320.

Wu, G.J., Pan, B.T., Guan, Q.Y., Wang, J.M., Zhao, Z.J., 1998. Climatic changes in the North Piedmont of Eastern Qilian mountains since 10 Ka B.P. Journal of Desert Research 18 (3), 193-200 (in Chinese with English Abstract).

Wu, Y.H., Lücke, A., Jin, Z.D., Wang, S.M., Schleser, G., Battarbee, R.W., Xia, W.L., 2006 Holocene climate development on the central Tibetan Plateau: a sedimentary record from Cuoe Lake. Palaeogeography, Palaeoclimatology, Palaeoecology 234, 328-340.

Wu, H., Guiot, J., Brewer, S., Cuo, Z., 2007a. Climate changes in Eurasia and Africa at the last Glacial maximum and mid-Holocene: reconstruction from pollen data using inverse vegetation modeling. Climate Dynamics 29, 211-229.

Wu, Y.H., Lücke, A., Wünnemann, B., Li, S.J., Wang, S.M., 2007b. Holocene climate change in the central Tibetan Plateau inferred by lacustrine sediment geochemical records. Science in China Series D: Earth Sciences 50 (10), 1548-1555.

Wu, H.N., Ma, Y.Z., Feng, Z.D., Sun, A.Z., Zhang, C.J., Li, F., Kuang, J., 2009. A high resolution record of vegetation and environmental variation through the last 25,000 years in the western of Chinese Loess Plateau. Palaeogeography, Palaeoclimatology, Palaeoecology 273, 191-199.

Xiao, J.L., Nakamura, T., Lu, H.Y., Zhang, G.Y., 2002. Holocene climate changes over the desert/loess transition of north-central China. Earth and Planetary Science Letters 197, 11-18.

Xiao, J.L., Xu, Q.H., Nakamura, T., Yang, X.L., Liang, W.D., Inouchi, Y., 2004. Holocene vegetation variation in the Daihai Lake region of north-central China: a direct indication of the Asian monsoon climatic history. Quaternary Science Reviews 23 1669-1679.

Xiao, J.L., Wu, J.T., Si, B., Liang, W.D., Nakamura, T., Liu, B.L., Inouchi, Y., 2006. Holocene climate changes in the monsoon/arid transition reflected by carbon concentration in Daihai Lake of Inner Mongolia. The Holocene 16, 551-560.

Xiao, J.L., Si, B., Zhai, D.Y., Itoh, S., Lomtatidze, Z., 2008. Partitioning of the grain-size components of Dali Lake core sediments: evidence for lake-level changes during the Holocene. Journal of Paleolimnology 40, 519-528.

Xue, B., Qu, W.C., Wang, S.M., Ma, Y., Dickman, M.D., 2003. Lake level changes documented by sediment properties and diatom of Hulun Lake, China since the late Glacial. Hydrobiologia 498, 133-141.

Xue, J.B., Zhong, W., Zhao, Y.J., Peng, X.Y., 2008. Holocene abrupt climate shifts and midHolocene drought intervals recorded in Barkol Lake of Northern Xinjiang of China. Chinese Geographical Science 18 (1), 54-61.

Yan, G., Wang, F.B., Shi, G.R., Li, S.F., 1999. Palynological and stable isotopic study of palaeo-environmental changes on the northeastern Tibetan plateau in the last 30,000 years. Palaeogeography, Palaeoclimatology, Palaeoecology 153, 147-159.

Yao, T.D., Thompson, L.G., 1992. Trends and features of climatic changes in the past 5000 years recorded by the Dunde ice core. Annals of Glaciology 16, 21-24.

Yuan, D.X., Cheng, H., Edwards, R.L., Dykoski, C.A., Kelly, M.J., Zhang, M.L., Qing, J.M., Lin, Y.S., Wang, Y.J., Wu, J.Y., Dorale, J.A., An, Z.S., Cai, Y.J., 2004. Timing, duration, and transitions of the last Interglacial Asian monsoon. Science 204, 575-578.

Zhang, X.Y., Gong, S.L., Zhao, T.L., Arimoto, R., Wang, Y.Q., Zhou, Z.J., 2003. Sources of Asian dust and role of climate change versus desertification in Asian dust emission. Geophysical Research Letters 30 (24), 2272-2275.

Zhang, M.L., Yuan, D.X., Lin, Y.S., Qin, J.M., Li, B., Cheng, H., Edwards, R.L., 2004. A 6000year high-resolution climatic record from a stalagmite in Xiangshui Cave. Guilin, China, The Holocene 14, 697-702.

Zhao, Q., Wang, N.A., Cheng, H.Y., Kan, Y.S., Guo, J.Y., 2003. Grain-size characteristics of Qingtu Lake sediments and its paleaoenvironment explanation. Arid Land Geography 26 (1), 1-5 (in Chinese with English Abstract).

Zhao, H., Chen, F.H., Li, S.H., Wintle, A.G., Fan, Y.X., Xia, D.S., 2007a. A record of Holocene climate change in the Guangzhong Basin, China, based on optical dating of a loesspalaeosol sequence. The Holocene 17, 1015-1022.

Zhao, Y., Yu, Z.C., Chen, F.H., Ito, E., Zhao, C., 2007b. Holocene vegetation and climate history at Hurleg Lake in the Oaidam Basin, northwest China. Review of Palaeobotany and Palynology 145, 275-288. 
Zhao, Y., Yu, Z.C., Chen, F.H., Zhang, J.W., Yang, B., 2009. Vegetation response to Holocene climate change in monsoon-influenced region of China. Earth Science Reviews 97, 242-256.

Zhou, W.J., Donahue, D.J., Porter, S.C., Jull, T.A., Li, X.Q., Stuiver, M., An, Z.S., Matsumoto, E., Dong, G.R., 1996. Variability of monsoon climate in east Asia at the end of the last Glaciation. Quaternary Research 46, 219-229.

Zhou, W.J., Head, M.J., Lin, D., 2001. Climate changes in northern China since the late Pleistocene and its response to global change. Quaternary International 83-85, 285-292.

Zhou, W.J., Lu, X.F., Wu, Z.K., Deng, L., Jull, A.J.T., Donahue, D., Beck, W., 2002. Chinese Science Bulletin 47 (1), 66-70.
Zhu, L.P., Wu, Y.H., Wang, J.B., Lin, X., Ju, J.T., Xie, M.P., Li, M.R., Mäusbacher, R., Schwalb, A., Daut, G., 2008. Environmental changes since 8.4 ka reflected in the lacustrine core sediments from Nam Co, central Tibetan Plateau, China. The Holocene 18, 831-839.

Zhu, L.P., Zhen, X.L., Wang, J.B., Lv, H.Y., Xie, M.P., Kitagawa, H., Possnert, G., 2009. A 30, 000-year record of environmental changes inferred from Lake Chen Co, southern Tibet. Journal of Paleolimnology 42 (3), 343-358.

Zuur, A.F., Leno, E.N., Smith, G.M., 2007. Analysing Ecological Data. Springer, New York. $672 \mathrm{pp}$.

Zveryaev, I.I., Aleksandrova, M.P., 2004. Differences in rainfall variability in the south and Southeast Asian summer monsoons. International Journal of Climatology 24, 1091-1107. 